Savunma Bilimleri Dergisi

The Journal of Defense Sciences

Mayıs/May 2019, Cilt/Volume 18, Sayı/Issue 1.

ISSN (Bas1l1) : 1303-6831 ISSN (Online): 2148-1776

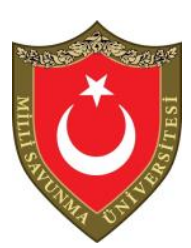

\title{
Girişimcilik Eğilimini Etkileyen Faktörlere İlişsin Çok Boyutlu Bir Analiz: Orta Öğretimde Bir Araştırma*
}

\author{
Aykut GÖKSEL*** ve Serhat ULUCAN*** \\ $\ddot{O} z$
}

Girişimcilik, ülkelerin gelişiminde, dengeli bir kalkınma süreci izlenmesinde, toplumların refahının artmasında ve yaşam standartlarının yükselmesinde önemli bir yere sahiptir. Bu bakımdan toplumu oluşturan bireylerin girişimcilik eğilimlerinin ve bu eğilimleri etkileyen faktörlerin tespit edilmesi, toplumların girişimcilik potansiyelleri hakkında bizlere bilgi verebilir ve sonraki çalışmalar için yol gösterebilir. Bireylerin, azimli ve rekabetçi olmaları, yeni iş kurmalarındaki karşılaştıkları güçlükler, yenilikçi ve yaratıcı özellikleri, riskten kaçınma dereceleri, ailelerinin verdikleri destekler, azim ve kararlılıkları ile demografik özellikleri girişimcilik eğilimlerinin eyleme geçmesinde etkili olacaktır. Bu çalışmayla, Ankara ilinde, farklı ilçelerden seçilmiş çeşitli liselerde okuyan son sinıf öğrencilerin girişimcilik ĕgilimlerini, girişimcilik ĕgilimlerini etkileyen faktörleri tespit etmek amaçlanmıştır. Ayrıca girişimcilik eğilimi kapsamında; cinsiyet, öğrencilerin öğrenim gördükleri okullar ve girişimcilik dersi alma durumuna ilişkin hipotezler oluşturulup test edilmiş ve sonuçlar değerlendirilmiştir. Elde edilen sonuçlar neticesinde, öğrencilerin girişimcilik ĕgilimi açısından cinsiyetin etkisinin olmadĭ̆ tespit edilmiştir. Öğrencilerin öğrenim gördükleri okullar ile girişimcilik eğilimi arasında ise anlamlı bir fark bulunamamıştır. En son olarak lise öğreniminde girişimcilik dersi almanın, bireylerin girişimcilik eğilimine pozitif yönde katkl sağladiğı tespit edilmiştir.

Anahtar Kelimeler: Girişsimcilik, Girişimcilik Eğilimi, Girişsimcilik Eğitimi.

* $\mathrm{Bu}$ çalışma Doç.Dr.Aykut GÖKSEL'in danışmanlığında hazırlanan “Girişimcilik Eğiliminin ve Girişimcilik Eğilimini Etkileyen Faktörlerin Analizi: Ortaöğrenimde Lise 3. ve 4. Sınıf Öğrencileri Üzerinde Bir Uygulama” başlıklı yüksek lisans tezi esas alınarak hazırlanmıştır."

** Doç.Dr., Ankara Hacı Bayram Veli Üniversitesi İktisadi ve İdari Bilimler Fakültesi, İşletme, Yönetim ve Organizasyon A.B.D. agoksel@gazi.edu.tr ; aykut.goksel@ hbv.edu.tr *** Milli Savunma Bakanlığı, sulucan1998@hotmail.com

Geliş Tarihi/Received:27.09.2018

Kabul Tarihi/Accepted:14.03.2019

Araştırma Makalesi/Research Article 


\title{
A Multidimensional Analysis on the Factors Affecting Entrepreneurial Tendency: A Research on High School Students at the Secondary Education
}

\begin{abstract}
Entrepreneurship has an important role in the development of countries, increasing the wealth and life standards of societies. In this case, establishing the entrepreneurship tendency of people and the affecting the factors of this tendency would give us specified information about entrepreneurship potential of societies. Moreover, it would guide the other researches onthis topic. To competitiveness, difficulties of starting up a new firm, innovative and creative features, the degree of avoiding risk, family support, decisiveness, need of success and demographic characteristics of individuals would be effective on the action of entrepreneurship. With this study, it is aimed to determine the entrepreneurship tendencies and the factors affecting the entrepreneurship tendencies of senior students in various high schools selected from different districts in Ankara. Also within the scope of entrepreneurship tendency; hypothesis about gender, the schools where students learn and take the course of entrepreneurship were created and tested and last the results were evaluated. The results obtained put forward that there is no gender effect in terms of the entrepreneurship tendency of the students. There is no significant difference between the tendency of entrepreneurship and the schools where students were educated. Finally, it is found that taking entrepreneurship lessons in high school education contributes to the entrepreneurship tendency positively.
\end{abstract}

Keywords: Entrepreneurship, Entrepreneurship Tendency, Entrepreneurship Education.

\section{Giriş}

Günümüzde kişilerin yaptı̆̆ 1 yeni yatırımlar neticesinde elde edilen yeni buluşlar bir girişimcilik örneği olarak karşımıza çıkabilmekte ve ülke ekonomilerine yön verebilmektedir. Girişimcilik, günümüzde gelişmiş ülkelerin ekonomik temelini oluşturan büyük bir güçtür. İşte bu noktada yeni iş fikirlerini hayata geçirebilecek genç nüfusun girişimcilik eğilimi arttıkça, girişimci bireylerin sayısı ve dolayısıyla da ülkelerin gelişmişlik düzeyi artacaktır. 
Girişimcilik Eğilimini Etkileyen Faktörlere İlişkin Çok Boyutlu Bir Analiz:

Orta Öğretimde Bir Araştırma

Çalışmada, Ankara ilinde 9'uncu ve 10'uncu sınıf öğrencilerinin girişimcilik eğilimleri ile bu eğilimleri etkileyen faktörler tespit edilmeye çalışılmış, cinsiyet, okul türü ve girişimcilik dersi alma gibi faktörlerin girişimcilik eğilimi ile olan ilişkisi incelenmiştir. Araştırma Ankara ili, Etimesgut, Yenimahalle, Çankaya ve Mamak ilçelerinden seçilen Anadolu Lisesi, İmam Hatip Lisesi, Fen Lisesi, Ticaret Meslek Lisesi, Teknik ve Endüstri Meslek Lisesi ve Kız Meslek Lisesi türündeki toplam 20 okuldan 9'uncu ve 10'uncu sinıflarda okuyan 1431 öğrenciye yüz yüze anket yöntemi uygulanarak yapılmıştır.

\section{Kuramsal Çerçeve}

\section{Girişimcilik ve Girişimcilik Eğilimi}

Girişimcilik kavramı, ortaya çıktığı 17. yüzyıldan beri gerek özellikleri gerekse toplumsal hayata etkileri açısından çok boyutlu bir anlam ifade etmektedir. Girişimcilik tanımı içerisinde yer alan en önemli özelliklerden "yenilik" kavramına ilk vurgu yapan araştırmacılardan olan Schumpeter, girişimciliği, "ticari amaçlı ekonomik değer taşıyan yenilik etkinlikler" olarak tanımlamaktadır (Shumpeter, 1973), (Brockhaus ve Horwitz, 1986:25). Arıkan, girişimciliği daha önceden rutin ve sıradan iş süreçlerinde yapılmayan farklı bir şeyler yapmak olarak tanımlamıştır (Arıkan, 2004:50). Bu tanımlamalar bize girişimcinin "yenilik yaratma" boyutunu vurgulamaktadir.

Gartner'ın (1988) girişimcilik tanımı ise kavramın örgütsel köklerine vurgu yapmaktadır. Gartner girişimciliği örgütsel bir olay ve yenilikçi bir örgüt yaratma süreci olarak görmüştür (Gartner, 1988:11). Hisrich (1985) ise girişimciliği "bir süreç ve bu süreci çeşitli risklerle birlikte parasal ve kişisel anlamda tatmin elde etme" olarak nitelendirmiştir (Erdoğmuş, 2007). Bu çerçevede ele alındığında girişimcinin "başarı ihtiyacı" boyutuna atıfta bulunulduğu görülmektedir. Dollinger ise girişimciliği yenilikçilik temelinde, risk ve belirsizlik koşulları altında ekonomik kazanç elde etmek için bir ekonomik örgütün oluşturulması olarak nitelemiştir (Dollinger, 1999:4).

Knight'a göre girişimci olmak belirli oranda riski üstlenmenin yanında asıl olarak gerçek belirsizliği üstlenmektedir (Praag ve Mirjam, 1999:147, 322). Bu çerçevede ele alındığında girişimcinin "risk alma" davranışı öne çıkmaktadır. 
Shane ve Eckhardt girişimciyi bir kâşif gibi görmüş ve girişimcilik kavramını gelecek mal ve hizmetlerin keşfi olarak tanımlamıştır (Stevenson, 2005:43).

Bozkurt, girişimciliği firsatlara yönelik projeler yaparak bunları günlük hayata entegre etme ve yaratılan değer ile hayatı daha yaşanabilir hale getirme uğraşı olarak tanımlamaktadır (Bozkurt, 2000: 86-94). Bygrave ve Hofers'e göre girişimciliğin içerisinde firsatlar temelinde işletmesini şekillendirme yatmaktadır (Mueller ve Anisya, 2001: 51-75). Bu tanımlamalar çerçevesinde ele alındığında girişimcinin "kendi işini kurma fırsatı ve çalışma" boyutu öne çıkmaktadır. Fırsat ve örgütlenme becerisi açısından girişimcilik tanımına yaklaşan Morris'e göre girişimcilik, bir firsattan faydalanmak için kaynakların eşsiz bir bileşimini bir araya getirerek değer yaratma sürecidir (Lin,Li ve Chen, 2006: 168-181).

Girişimci olmayı etkileyen faktörler arasında en önemlilerinden birisi de aile faktörüdür. Kişinin çocukluğundan bu yana ailesi tarafından yetiştirilme tarzı, verdiği kararlarda aile desteğinin olması ve kişinin girişimcilik anlayışının aile tarafindan onaylanması girişimci olma konusunda başlıca motivasyon faktörleri arasında sayılabilir. Eğer aile ve çevre içerisinde girişimcilik destekleniyorsa kişi yeterli donanıma ve maddi olanaklara sahip olduğunda girişimci kültürü yerleşmiş olur (Demircan, 2000: 24).

Ekonomik ortamın uygunsuz oluşu, karmaş̧1k ve idari süreçlerin varlığ , yetersiz finansman desteği ve negatif faktörler girişimcilerin karşısına yeni iş kurma konusunda bir zorluk olarak çıkmaktadır. Toplumun girişimcilere verdiği değer ve onların iş kurma noktasındaki cesaretini teşviki başarılı olan girişimciler yanında başarısız olanlara da yeni bir şans verilmesini kapsamalıdır. Hümanizm faktörü olarak ele alınan bu faktör içerisinde toplumun başarılı olanların yanında başarısız girişimcileri de içermesi bireylerin girişimci olma motivasyonunu etkileyen faktörler arasındadır. Ekonomik ve sosyal faktörler gibi çevresel faktörlerden farklı olarak psikolojik faktörler daha bireysel ve kişinin kendi düşünce yapısı ile doğrudan ilgili bir yapıya sahiptirler. Girişimci olmayı belirleyen psikolojik faktörlerin başında kontrol odağı gelmektedir. İçsel ve dışsal kontrol odağı ile ilgili literatürde çeşitli görüşler mevcuttur. Brockhaus ve Horwitz kontrol odağını (Locus of Control) kişinin hayatında meydana gelen olaylar ya da bunların sonuçlarını kendi kontrolünde veya kendi kontrolü dışında olarak algılaması durumu olarak ifade etmektedir (Brockhaus ve Horwitz, 1986: 25). 
Girişimcilik Eğilimini Etkileyen Faktörlere İlişkin Çok Boyutlu Bir Analiz:

Orta Öğretimde Bir Araştırma

\section{Girişimciliğin Ekonomik ve Sosyal Kalkınma Açısından Önemi}

Girişimcilik ekonomik kalkınmanın itici gücü olarak kabul edilmektedir. Kavramın özünde yer alan yenilik ve yaratıcılık kavramları ekonominin daha yüksek düzeyde bilgi odaklı hale gelmesine katkıda bulunurken, girişimci bireylerin ekonomi içerisindeki varlığı buradaki insan faktörüne de vurgu yapmaktadır. Girişimcilik kavramının ekonomik kalkınmadaki yeri, içinde faaliyet gösterilen ekonomideki girişimci ekosistemin varlığı ve nitelikleri ile doğrudan ilgilidir. Girişimci ekosistem kavramı girişimcilik olgusunun gelişmiş olduğu ekonomilerde sıklıkla kullanılmakla birlikte, içerik bakımından "Nasıl girişimci ekonomi olunur?" sorusuna cevap niteliği taşımaktadır. Financial Times'ın tanımına göre, özel ve kamu aktörlerinin bir arada olduğu bir yapıyı anlatan “Girişimci Ekosistem”; ülkenin üretim gücünü, bilgi birikimini ve vizyonunu yeni girişimcilere anlatabilme yeteneği ile ilgilidir (Financial Times, 2014). Girişimcilik ekosistemi içerisinde yarışma ve ödüller girişimcilik kültürünün oluşmasında önemli bir etkendir. Türkiye'de girişimciliğin geliştirilmesi ve teşvik edilmesi maksadıyla "KOSGEB KOBİ ve Girişimcilik Ödülleri”; Yılın Başarılı KOBİ Büyük Ödülü, Yılın Başarılı KOBİ Ödülleri ve Yılın Başarılı Girişimci Ödülleri olmak üzere üç ana kategoride verilmektedir ( KOSGEB Ödülleri, 2013).

Girişimcilik kavramı ekonominin yanında sosyal hayatı da etkilemektedir. Kaynakları bir araya getirme sürecinde girişimcinin rolü toplum açısından öncü olmak ve toplumu yeni bir ürün veya hizmet ile tanıştırarak onun kendini geliştirmesini sağlamaktır (Yelkikalan, 2010: 52). Girişimciliğin özündeki yenilik unsuru insan kaynaklarının yeterli seviyede kullanılabilmesi için bir gelişme gereksinimi doğurmakta, bu da toplumun sosyal seviyesini (eğitim, kültür, dil vb.) geliştirmektedir. İnsan kaynaklarının daha verimli kullanılması konusunda girişimciliğin getirdiği olumlu etki, kamu istihdamının toplam istihdam içerisindeki payının azaltılmasına katkıda bulunmakta ve bu yolla insan kaynaklarının sosyal kalkınmaya daha doğrudan etkisi bulunan piyasa ekonomisine yönlendirilmesini sağlamaktadır (İlhan, 2004: 72).

Araştırmacılar din, ırk, sosyal çevre, toplumsal önyargılar, tarihsel koşullar, etnik yapı vb. gibi kar dışındaki unsurların girişimciliği etkileyen önemli unsurlar arasında bulunduğu üzerinde durmuşlardır (Verheul, 2003). Girişimcilikte kar dışı faktörlerin rolüne ilk olarak Max Weber değinmiştir. Weber kapitalizmin diğer medeniyetlere göre batıda neden daha başarılı olduğunu açıklayabilmek 
amacı ile çok yönlü bir araştırma ortaya koymuştur. Weber'in modelinin sosyal yönü "Protestan Çalışma Ahlakı" olarak tanımlanmıştır. Buradan hareketle kültür girişimsel faaliyetleri açıklamada önemli bir değişken olarak ele alınmaktadır. Kanaatkâr olma, tutumluluk, çilecilik gibi kültürel değerlere sahip olan grupların girişimcilik düzeyinin veya girişimsel performanslarının diğerlerine nazaran daha düşük olabileceği Weber'in ele aldığı konular arasındadır (Demirez ve Cebeci, 2005: 38). Ayrıca Weberci bakış açısından, İslam toplumlarının girişimciliği veya kapitalizmin ruhunu geliştirmede üç dezavantajı vardır: Bunlar; doğuya özgü merkeziyetçi zorlayıc1 yapı, savaşçı ahlakı ve diğer dünyevi Sufizm'dir. Osmanlının bu merkeziyetçi zorlayıcı tutumu 1839'dan itibaren yapılan reformlar ile azalmaya başlamış ve Osmanlının son dönemlerinde özel mülkiyet haklarıda güvence altına alınmıştır (Arslan, 2000: 389).

\section{Girişimcinin Özellikleri}

Girişimci kavramı araştırmacılar tarafından çok boyutlu bir şekilde incelenmiş ve birçok özelliği ortaya konmuştur. Girişimcilik kavramının ekonomik içeriğinin yanında sosyal ve kültürel açıdan da anlam taşıması sebebiyle girişimcinin özellikleri bu boyutlardan da ele alınmış ve girişimci bireyler psikolojik özelliklerinin yanında her şeyden önce yaşadıkları sosyo ekonomik çevrenin bir ürünü olarak değerlendirilmişlerdir (Bozkurt ve Alparslan, 2013: 10).

Girişimcilerin taşıdıkları özellikler ile ilgili çeşitli görüşler bulunmaktadır. $\mathrm{Bu}$ özellikler niteliklerine göre doğuştan ya da sonradan kazanılabilen veya psikolojik ile sosyal temelli bazı farklı perspektifler ile ayrılabilmektedir. Hofstede (1980)'nin milli kültürlere dayanarak ortaya koyduğu konsepti ele alarak (bireycilik-toplumculuk, belirsizlikten kaçınma erillik-dişilik ve güç mesafesi), kültür ve girişimcilik üzerine yapılmış birçok çalışma bulunmaktadır (Hayton, George ve Zahra, 2002) (Hisrich, 2007). Ancak bu görüşler çerçevesinde genel kabul görmüş özellikler listesi oluşturmanın zorluğundan dolayı öne çıkan genel özellikler Tablo 1'de sunulmuştur. 
Girişimcilik Eğilimini Etkileyen Faktörlere İlişkin Çok Boyutlu Bir Analiz:

Orta Öğretimde Bir Araştırma

Tablo 1. Girişimci Özellikleri ve Literatür Taraması

\begin{tabular}{|l|l|}
\hline \multicolumn{1}{|c|}{ Nitelik } & \multicolumn{1}{|c|}{ Araştırmacılar } \\
\hline Yenilikçi & $\begin{array}{l}\text { Herron,1992; Geisler,1993; Drucker, 1998b; Daft,2005; } \\
\text { Hisrich vd., 2005; Hitt vd.,2005; Küçük,2005 }\end{array}$ \\
\hline \multirow{2}{*}{ Risk alan } & $\begin{array}{l}\text { Geisler,1993; Johnson ve Hayes,1996; Drucker,1998; } \\
\text { Hisrich vd., 2005, Hitt vd., 2005; Küçük,2005; Zhao vd., } \\
\text { 2005; Hewison/Badger, 2006, Shapero, }\end{array}$ \\
\hline Değiş̧im Odaklı & $\begin{array}{l}\text { Luchsinger/Bagby,1987; Herron,1992; Hisrich vd.,2005; } \\
\text { Hitt vd.,2005 }\end{array}$ \\
\hline Fırsatlara Odaklanmış & Corbett/Hmieleski, 2005; Hitt vd.,2005 \\
\hline Yaratıcı & Daft,2005; Hitt vd.,2005; Hewison/Badger,2006 \\
\hline Gelişmiş İletişim Becerisi & Hitt vd.,2005 \\
\hline Proaktiflik & Hisrich vd.,2005 \\
\hline Yüksek Başarı Güdüsü & Daft,2005 \\
\hline Duygusal Zeka & Hitt vd.,2005 \\
\hline Kararlarda Israrcılık & Akyüz, Gedik, Yıldırım,2006 \\
\hline İşbirliği Yapma & Luttunen,2000 \\
\hline Teknik Bilgi Üretebilme & Luttunen,2000 \\
\hline Çok Yönlü Düşünme & Akyüz, Gedik, Yıldırım,2006 \\
\hline İyi Gözlemci Olma & Levenburg, 2006 \\
\hline Öğrenmeye Açık Olma & Casson, 2003 \\
\hline Kaynak: İsan Ö, Kaygın E
\end{tabular}

Kaynak: İşcan Ö, Kaygın E, 2011; Bayraktar S., 2011; Arthur S.J., Hisrich R.D.2011; Bozkurt Ö., 2011; Özkan Ş. vd. 2003; Akyüz C. vd. 2006'dan yararlanılarak hazırlanmıştır.

\section{Türkiye'de Girişimcilik Eğitimi}

Türkiye'de finansal liberalizasyon hareketlerinin öncesindeki kapalı ekonomik model iş dünyasını global rekabet ortamından uzak tutarak, iç piyasada hakim olmanın verdiği rehavetle karlarını korumaya çalışan, siyasi ve ekonomik belirsizlikler içinde risk almaktan çekinen bir ortam yaratmıştır. Günümüzde sınırların ortadan kalktığ 1 ekonomik sistemde rekabetten uzak durabilmek neredeyse hiçbir işletme ya da sektör için imkan dahilinde değildir. Söz konusu gelişmeler Türkiye ekonomisi için de geçerli olup, son yıllarda girişimciliğin önemi kavranmış ve gerek devlet gerekse özel sektör kuruluşlarının katkılarıyla, girişimcilik konusunda yeni çalışmalar yapılmaya başlanmıştır (Sönmez, 2014). Sanayi ve Ticaret Bakanlığı tarafından hazırlanan 2011-2014 Türkiye Sanayi 
Strateji Belgesinde girişimciliğe ilişkin temel sanayi politikası öncelikleri arasında KOBİ'lerin ve girişimlerin rekabet güçlerinin artırılması için eğitim ve danışmanlık hizmetlerinin sağlanması ve bu kapsamda piyasadaki yatırımcıların daha doğru karar vermesine imkân tanıyacak bir "Girişimci Bilgi Sistemi” kurulması planlanmıştır. KOSGEB tarafından hazırlanan 2011-2013 KOBİ Stratejisi ve Eylem Planında da girişimcilik kalkınma için ana başlıklardan birisi olarak ele alınmış ve plandaki beş ana stratejik hedeften birisi olarak girişimciliğin geliştirilmesi ve desteklenmesi belirlenmiştir. Bölgesel Kalkınma Ajansları da oluşturdukları bölge planlarında girişimciliği artırmanın bölgesel kalkınma için büyük önem arz ettiğini belirlemiş ve bu alanda stratejiler geliştirmişlerdir. Bununla birlikte 10. Ulusal Kalkınma planında da ülkedeki girişimcilik düzeyinin hızlandırıcı mekanizmalar vasıtası ile yenilik temelli olarak artırılması ana stratejilerden birisi olmuştur (Onuncu Y1l Kalkınma Planı, 2104-2018). Ancak girişimci birey yetiştirmenin temeli eğitimden geçmektedir.

Türkiye'de girişimcilik eğitimi yeterli olmasa da bazı üniversitelerin girişimcilik ve girişimcilik eğitimi üzerinde durduğu görülmektedir. Gürol, Aydınlık ve Arslan'ın 2008 yılında yaptığı çalışmada ülkemizde girişimcilik derslerinin verildiği toplam 47 devlet üniversitesi, 4 özel üniversite ile 19 vakıf üniversitesinin olduğu, 4 üniversitede ise genç girişimci geliştirme programı olduğu belirtilmiştir (Yelkikalan, 2010: 55-58). Türkiye'de girişimcilik eğitimi yaygın olmasa da orta ve yükseköğrenimde verilmeye başlanmıştır. Ancak girişimcilik işin gereken iş planlaması üretim ve pazarlama sürecinde karşılaşılabilecek yasal ve yasal olmayan problemlerin aşılması için gerekli olan eğitim hala mesleki eğitim içerisinde gösterilmektedir. Türkiye, girişimciliği, mesleki eğitimi ve nitelikli iş gücü sayısını artırabilmek için, AB'nin açmış olduğu, her yaştan ve meslekten insan yetiştirmenin amaçlandığı Leanardo Da Vinci ve Socrates programlarına 2004 yılı Nisan ayında katılmıştır (Küçüktekin, 2006: 8283). Girişimcilik konusu Hayat Boyu Öğrenme Strateji Belgesi (2010-2013), Milli Eğitim Bakanlığı Stratejik Planı (2010-2014) ve ilk ve ortaöğretim okullarının bireysel stratejik planları kapsamına alınmıştır. İlk ve ortaöğretim okullarında girişimcilik odaklı AB projeleri yürütülmektedir (Türkiye Girişimcilik Stratejisi ve Eylem Planı 2014-2016, 2013: 83). 
Girişimcilik Eğilimini Etkileyen Faktörlere İlişkin Çok Boyutlu Bir Analiz:

Orta Öğretimde Bir Araştırma

Tablo 2. Türkiye'de Girişimcilik Eğitimi ile İlgili Çalışmalar

\begin{tabular}{|c|c|c|}
\hline Yazarlar & Yılı & Başlı̆̆ı \\
\hline $\begin{array}{l}\text { Nuray Girginer, } \\
\text { Nurullah Uçkun }\end{array}$ & 2004 & $\begin{array}{l}\text { İşletmecilik Eğitimi Alan Lisans Öğrencilerinin } \\
\text { Girrişimciliğe Bakış Açıları: Eskişehir Osmangazi } \\
\text { Üniversitesi İ.İ.B.F İşletme Bölümü Öğrencilerine } \\
\text { Yönelik Bir Uygulama (Bildiri). }\end{array}$ \\
\hline $\begin{array}{l}\text { Yonca Gürol, } \\
\text { Nuray Atsan }\end{array}$ & 2006 & $\begin{array}{l}\text { Entrepreneurial Characteristic amongst University } \\
\text { Students: Some Insights for Entrepreneurship } \\
\text { Education and Training in Turkey (Makale). }\end{array}$ \\
\hline Dilek Eyüboğlu & 2007 & Girişimcilik Eğitimi (Kitap). \\
\hline $\begin{array}{l}\text { Özlem Balaban, } \\
\text { Yasemin Özdemir }\end{array}$ & 2008 & $\begin{array}{l}\text { Girişimcilik Eğitiminin Girişimcilik Eğilimi } \\
\text { Üzerindeki Etkisi: Sakarya Üniversitesi İİBF } \\
\text { Örneği (Makale) }\end{array}$ \\
\hline $\begin{array}{l}\text { Hasan Tağraf, } \\
\text { Muhsin Halis }\end{array}$ & 2008 & $\begin{array}{l}\text { Üniversitelerdeki Girişimcilik Eğitiminin } \\
\text { “Girişimsel Öz Yetkinlik” Algısı Üzerindeki } \\
\text { Etkisi: Bir Araştırma (Makale). }\end{array}$ \\
\hline $\begin{array}{l}\text { İsa İpçioğlu, } \\
\text { Atıl Taşer }\end{array}$ & 2009 & $\begin{array}{l}\text { İşletme Bölümlerinde Verilen Eğitimin Girişimci } \\
\text { Adayı Öğrenciler Üzerindeki Etkileri (Makale). }\end{array}$ \\
\hline Ertuğrul Berk & 2009 & $\begin{array}{l}\text { Girişimcilik Dersinin Etkililiğinin } \\
\text { Değerlendirilmesi (Makale). }\end{array}$ \\
\hline $\begin{array}{l}\text { Hatice Baysal, } \\
\text { Ahmet Sait Özkul }\end{array}$ & 2009 & $\begin{array}{l}\text { Türkiye'de Girişimcilik Eğitiminde İlköğretimin } \\
\text { Rolü Ders Kitapları Üzerine Bir İçerik Analizi } \\
\text { (Bildiri). }\end{array}$ \\
\hline Yasin Karadeniz & 2010 & Türkiye'de Girişimcilik Eğitimi (Makale). \\
\hline $\begin{array}{l}\text { N.Yelkikalan, Ayten Akatay, } \\
\text { H. Mehmet Yıldırım, } \\
\text { Yasin Karadeniz, Can Köse, } \\
\text { Öznur Koncagül, Eray Özer }\end{array}$ & 2010 & $\begin{array}{l}\text { Dünya ve Türkiye Üniversitelerinde Girişimcilik } \\
\text { Eğitimi: Karşılaştırmalı Bir Analiz (Makale). }\end{array}$ \\
\hline $\begin{array}{l}\text { Hasan İbicioğlu, } \\
\text { Sebahattin Taş, } \\
\text { İbrahim Özmen }\end{array}$ & 2010 & $\begin{array}{l}\text { Üniversite Eğitiminin Girişimcilik Düşüncesinin } \\
\text { Değişimine Etkisi: Üniversite Öğrencileri Üzerine } \\
\text { Bir Uygulama (Makale). }\end{array}$ \\
\hline $\begin{array}{l}\text { Sait Patır, } \\
\text { Mehmet Karahan }\end{array}$ & 2010 & $\begin{array}{l}\text { Girişimcilik Eğitimi ve Üniversite Öğrencilerinin } \\
\text { Girişimcilik Profillerinin Belirlenmesine Yönelik } \\
\text { Bir Alan Araştırması (Makale). }\end{array}$ \\
\hline
\end{tabular}




\begin{tabular}{|l|c|l|}
\hline \multicolumn{1}{|c|}{ Yazarlar } & Yllı & \multicolumn{1}{c|}{ Başlığı } \\
\hline $\begin{array}{l}\text { Burcu Selin Yılmaz, } \\
\text { Özgür Devrim Günel }\end{array}$ & 2011 & $\begin{array}{l}\text { Üniversite Eğitimi ve Girişimcilik: Bireyleri } \\
\text { Girişimciliğe Yönlendiren Etkenler Üzerine Bir } \\
\text { Araştırma (Makale). }\end{array}$ \\
\hline $\begin{array}{l}\text { Özlem Çetinkaya } \\
\text { Bozkurt }\end{array}$ & 2011 & $\begin{array}{l}\text { Dünyada ve Türkiye'de Girişimcilik Eğitimi: } \\
\text { Başarılı Girişimciler Ve Öğretim Üyelerinden } \\
\text { Öneriler (Kitap). }\end{array}$ \\
\hline $\begin{array}{l}\text { Aykut Göksel, } \\
\text { Belgin Aydıntan }\end{array}$ & 2011 & $\begin{array}{l}\text { Gender, Business Education, Family Background } \\
\text { and Personal Traits; a Multi Dimensional Analysis } \\
\text { of Their Affects on Entrepreneurial Propensity: } \\
\text { Findings from Turkey (Makale). }\end{array}$ \\
\hline $\begin{array}{l}\text { Seda Bayrakdar } \\
\text { Hengiz Duran, } \\
\text { Gülten Eren Gümüştekin }\end{array}$ & 2011 & $\begin{array}{l}\text { Avrupa Birliği Mesleki Eğitim Programlarında } \\
\text { Girişimcilik Eğitimlerinin Ekonomik } \\
\text { Kalkınmadaki Önemi (Makale). }\end{array}$ \\
\hline $\begin{array}{l}\text { Özlem Çetinkaya Bozkurt, } \\
\text { Ali Murat Alparslan }\end{array}$ & 2013 & $\begin{array}{l}\text { Girişimcilerde Bulunması Gereken Özellikler İle } \\
\text { Girişimcilik Eğitimi: Girişimci Ve Öğrenci } \\
\text { Görüşleri (Makale). }\end{array}$ \\
\hline $\begin{array}{l}\text { Selma Kalyoncuoğlu, Belgin } \\
\text { Aydıntan, Aykut Göksel }\end{array}$ & 2017 & $\begin{array}{l}\text { The Effect of Entrepreneurship Education on } \\
\text { Entrepreneurial Intention: An Experimental Study } \\
\text { on Undergraduate Business Students (Makale). }\end{array}$ \\
\hline $\begin{array}{l}\text { Kaynak: Makine Programı Örneği (Makale). } \\
\text { Mŏitimin Katkısı: Kütahya }\end{array}$
\end{tabular}

Kaynak: Bozkurt, Ö., Alparslan M. (2013), Girişimcilerde Bulunması Gereken Özellikler İle Girişimcilik Eğitimi: Girişimci ve Öğrenci Görüşleri, Girişimcilik ve Kalkanma Dergisi, (8:1), s.13-14'den derlenerek hazırlanmıştır.

Yelkikalan ve diğerlerinin (2010) üniversitelerin internet adreslerine ulaşılarak yaptığı araştırma neticesinde Türkiye'de 290 ön lisans bölümünde, 110 lisans bölümünde, 21 yüksek lisans bölümünde olmak üzere toplam 77 üniversitede girişimcilik dersi verildiği tespit edilmiştir. Türkiye'de verilen girişimcilik ders konuları genel olarak; girişimcinin özellikleri, girişimcilikte başarı ve başarısızlık faktörleri, kü̧̈ük işletmelerin güçlü ya da zayıf yönleri ile girişimcilerin ekonomik ve sosyal yönlere katkılarını ele almaktadır (Yelkikalan, 2010: 55-58). 
Girişimcilik Eğilimini Etkileyen Faktörlere İlişkin Çok Boyutlu Bir Analiz:

Orta Öğretimde Bir Araştırma

\section{Araştırma}

\section{Araștırmanın Amacı ve Yöntemi}

$\mathrm{Bu}$ çalışmanın temel amacı, seçilmiş lise öğrencilerinin farklı düzeyde girişimcilik eğilimlerine sahip olup olmadıklarını ortaya çıkarmak, girişimcilik eğilimlerini etkileyen faktörleri tespit etmek, girişimcilik eğilimini etkileyen faktörler var ise hangilerinde daha anlamlı fark olduğunu ve öne çıkan demografik özelliklerin bu faktörlerle olan ilişkisini araştırmaktır.

Ayrıca bu araştırma ile bugüne kadar üniversite öğrencileri üzerinde yapılarak tespit edilmiş olan girişimcilik eğilim ve potansiyellerini etkileyen faktörler orta öğrenim düzeyindeki öğrencilere anket uygulayarak ortaya konabilecek ve ortaöğrenim düzeyindeki öğrencilerin girişimcilik eğilimi bakımından ne düzeyde oldukları tespit edilebilecektir.

Girişimcilik eğilimini ölçmek için, Doğan (2013)'ın, azimli ve rekabetçi olma, yeni iş kurma güçlüğü, yenilik yaratma, riskten kaçınma, kendi işini kurma fırsatı ve çalışma, aile desteği, hümanizm faktörü ölçeği ile Üçok (2000) tarafindan yayınlanan McClelland (1965)'in başarı ihtiyacı faktörü ölçeği ve Rotter (1966)'nın kontrol odağı faktörü ölçeği kullanılmıştır. Girişimcilik eğilimini tespit için kullanılan ölçek (1) Kesinlikle Katılmıyorum, (2) Az Katılıyorum, (3) Katılıyorum, (4) Çok Katılıyorum, (5) Kesinlikle Katılıyorum şeklinde 5'li Likert tipinde gerçekleştirilmiştir.

Araştırmada veri toplama aracı olarak yüz yüze anket uygulamasından yararlanılmış, analizler SPSS ve SPSS AMOS programları kullanılarak gerçekleştirilmiştir. Çalışmanın ana kütlesini Ankara'da bulunan İmam Hatip Liseleri, Kız Teknik ve Meslek Liseleri, Anadolu Liseleri, Fen Liseleri ve Teknik ve Endüstri Meslek Liseleri'nde öğrenim görmekte olan lise öğrencileri oluşturmuştur. Araştırma Ankara ilinde bulunan 7 Anadolu Lisesi, 3 Fen Lisesi, 4 İmam Hatip Lisesi ve 6 Meslek Lisesi (Teknik, Ticaret, Endüstri) bünyesinde yer alan lise öğrencilerine anket formu uygulaması şeklinde yapılmışıı. Araştırmanın yapıldı̆̆ 1 dönemde derse katılmayan, hastalık ya da farklı nedenlerle araştırmaya katılmayı kabul etmeyen öğrenciler kapsam dışı bırakılmıştır. 


\section{Anakütle ve Örneklem}

Araştırma Ankara ilinde bulunan 7 Anadolu Lisesi, 3 Fen Lisesi, 4 İmam Hatip Lisesi ve 6 Meslek Lisesi (Teknik, Ticaret, Endüstri) bünyesinde yer alan 9'uncu (934 öğrenci) ve 10'uncu (497 öğrenci) sınıf öğrencilerine anket formu uygulaması şeklinde yapılmıştır. Çalışma kapsamında farklı liselerde 9'uncu ve 10'uncu sınıflarında okuyan lise öğrencilerine 1595 anket dağıtılmış, 1431 geçerli anket değerlendirme kapsamına alınmıştır. 2014 yılı itibari ile Ankara'daki lise öğreci sayısının 126 bin 894 (İnternet: Ankara Milli Eğitim Bakanlı̆̆ı, 29.04.2015), Türkiye'deki lise öğrenci sayısının 5 milyon 691 bin 071 olduğu bilinmektedir (Milli Eğitim İstatistikleri Örgün Eğitim, 2014-2015; 125).

Anakütle sayısı düşünüldüğünde örneklem sayısının 384 olmasının anakütleyi temsil etme açısından yeterli olacağı görülmektedir (Sekeran, 1992:253, Altunışık vd., 2004). Bu nedenle, elde edilen 1431 anket verisinin anakütleyi temsil etmesi açısından yeterli olduğu değerlendirilmektedir.

Çalışma kapsamında uygulanan anket sayıları Tablo 3'te yer almaktadır.

Tablo 3: Anketin Uygulandığı Öğrenci Sayıları

\begin{tabular}{|c|l|l|c|c|c|c|}
\hline $\begin{array}{c}\text { Sıra } \\
\text { No }\end{array}$ & \multicolumn{1}{|c|}{ Okul Adı } & İlçe & $\begin{array}{c}\text { Değerlendirilen } \\
\text { Anket }\end{array}$ & $\begin{array}{c}\text { Kategori } \\
\text { Dışı }\end{array}$ & Boş & Toplam \\
\hline 1 & $\begin{array}{l}\text { Abidinpaşa } \\
\text { Anadolu Lisesi }\end{array}$ & Mamak & 49 & 5 & 0 & 54 \\
\hline 2 & $\begin{array}{l}\text { Mehmetçik } \\
\text { Anadolu Lisesi }\end{array}$ & Etimesgut & 97 & 2 & 0 & 99 \\
\hline 3 & $\begin{array}{l}\text { Ümitköy Anadolu } \\
\text { Lisesi }\end{array}$ & Yenimahalle & 84 & 6 & 1 & 91 \\
\hline 4 & $\begin{array}{l}\text { Mehmetçik } \\
\text { Anadolu Lisesi }\end{array}$ & Etimesgut & 68 & 9 & 0 & 77 \\
\hline 5 & $\begin{array}{l}\text { Başkent Anadolu } \\
\text { Lisesi }\end{array}$ & Mamak & 79 & 20 & 0 & 99 \\
\hline 6 & $\begin{array}{l}\text { Dr. Binnaz Ege - } \\
\text { Dr. Rıdvan Ege } \\
\text { Anadolu Lisesi }\end{array}$ & Çankaya & 27 & 3 & 0 & 30 \\
\hline 7 & $\begin{array}{l}\text { Atatürk Anadolu } \\
\text { Lisesi }\end{array}$ & Yenimahalle & 25 & 3 & 0 & 28 \\
\hline
\end{tabular}


Girişimcilik Eğilimini Etkileyen Faktörlere İlişkin Çok Boyutlu Bir Analiz:

\begin{tabular}{|c|c|c|c|c|c|c|}
\hline $\begin{array}{c}\text { Sura } \\
\text { No }\end{array}$ & Okul Adı & İlçe & $\begin{array}{c}\text { Değerlendirilen } \\
\text { Anket }\end{array}$ & $\begin{array}{l}\text { Kategori } \\
\text { Dişı }\end{array}$ & Boş & Toplam \\
\hline 8 & $\begin{array}{l}\text { Başkent } \\
\text { Üniversitesi Özel } \\
\text { Ayşe Abla Fen } \\
\text { Lisesi }\end{array}$ & Çankaya & 26 & 0 & 0 & 26 \\
\hline 9 & Ankara Fen Lisesi & Çankaya & 68 & 3 & 0 & 71 \\
\hline 10 & $\begin{array}{l}\text { Özel Jale Tezer } \\
\text { Fen Lisesi }\end{array}$ & Çankaya & 79 & 7 & 0 & 86 \\
\hline 11 & $\begin{array}{l}\text { Cebeci Kız Teknik } \\
\text { ve Meslek Lisesi }\end{array}$ & Mamak & 75 & 7 & 0 & 82 \\
\hline 12 & $\begin{array}{l}\text { Ali Hasan Coşkun } \\
\text { Kız Teknik ve } \\
\text { Meslek Lisesi }\end{array}$ & Çankaya & 97 & 2 & 0 & 99 \\
\hline 13 & $\begin{array}{l}\text { Abidinpaşa Teknik } \\
\text { ve Endüstri Meslek } \\
\text { Lisesi }\end{array}$ & Mamak & 79 & 16 & 1 & 96 \\
\hline 14 & $\begin{array}{l}\text { Yunus Emre Kız } \\
\text { Teknik ve Meslek } \\
\text { Lisesi }\end{array}$ & Yenimahalle & 65 & 12 & 8 & 85 \\
\hline 15 & $\begin{array}{l}\text { Suzan-Mehmet } \\
\text { Gönç Ticaret } \\
\text { Meslek Lisesi }\end{array}$ & Mamak & 119 & 9 & 1 & 129 \\
\hline 16 & $\begin{array}{l}\text { Balgat Teknik ve } \\
\text { Endüstri Meslek } \\
\text { Lisesi }\end{array}$ & Çankaya & 99 & 10 & 1 & 110 \\
\hline 17 & $\begin{array}{l}\text { Mamak Anadolu } \\
\text { İmam Hatip Lisesi }\end{array}$ & Mamak & 84 & 16 & 0 & 100 \\
\hline 18 & $\begin{array}{l}\text { Şehit Nuri Pamir } \\
\text { Anadolu İmam } \\
\text { Hatip Lisesi }\end{array}$ & Mamak & 69 & 5 & 0 & 74 \\
\hline 19 & $\begin{array}{l}\text { Mamak Anadolu } \\
\text { İmam Hatip Lisesi }\end{array}$ & Mamak & 27 & 3 & 0 & 30 \\
\hline 20 & $\begin{array}{l}\text { Etimesgut İmam } \\
\text { Hatip Lisesi }\end{array}$ & Etimesgut & 115 & 8 & 6 & 129 \\
\hline \multicolumn{3}{|c|}{ Toplam } & 1431 & 146 & 18 & 1595 \\
\hline
\end{tabular}

Not: Ankete katılan öğrenciler tarafından eksik bırakılan soruların çokluğu ve verilen cevapların belli bir sistem içerisinde gelişi güzel cevap verilmesi "Kategori Dışı” bırakılan soruların nedenini oluşturmaktadır. 


\section{Analizler ve Bulgular}

\section{Doğrulayıcı Faktör Analizi}

Çalışma kapsamına alınan örneklemin yeterliliğini belirlemek amacıyla yapılan analiz sonuçlarına göre KMO değeri 0,821 olarak bulunmuştur. KMO testinin 1'e yakın olması anketin ana kütleyi temsil ettiğini göstermektedir. Bartlett testinin de anlamlılığının $\mathrm{p}=0,00$ olması, örneklemin yeterliliğini göstermekle birlikte, araştırma verilerinden anlamlı faktörler elde edilebileceğini ifade etmektedir.

Girişimcilik eğilimini ölçmek için, Doğan'ın (2013) azimli ve rekabetçi olma, yeni iş kurma güçlüğü, yenilik yaratma, riskten kaçınma, kendi işini kurma fırsatı ve çalışma, aile desteği, hümanizm faktörü ölçeği, Üçok(2000) tarafindan yayınlanan McClelland'ın (1965) başarı ihtiyacı faktörü ölçeği ve Rotter'ın (1966) kontrol odağ 1 faktörü ölçeği kullanılmıştır. Girişimcilik eğilimini tespit için kullanılan ölçek (1) Kesinlikle Katılmıyorum, (2) Az Katılıyorum, (3) Katılıyorum, (4) Çok Katılıyorum, (5) Kesinlikle Katılıyorum şeklindeki ifadelerden oluşan 5'li Likert tipinde hazırlanmıştır. Doğan'ın (2013) yılında yapmış olduğu araştırmanın girişimcilik eğilimine etki eden özelliklerine ilişkin incelenen soruların ölçeğine göre güvenilirlik analizi Cronbach's Alpha değeri 0,858 olarak hesaplanmıştır. Bu değer, ölçeğin güvenilir olduğunu göstermektedir. McClelland'ın (1965) başarı ihtiyacı faktörü ile Rotter'ın (1966) kontrol odağı faktörü ölçeği birçok araştırmada kullanılmış ve ölçeklerin güvenir olduğu belirtilmiştir.

Çalışmada kullanılan anket 2 kısımdan oluşmaktadır: 1'inci kısımda, öğrencilerin demografik özelliklerini tanımlamaya ilişkin sorular (20 tane), 2'nci kısımda, girişimcilik eğilimini ortaya koymaya yönelik ifadeler (53 tane) yer almaktadır. Anket formundaki 1'inci kısımdaki sorular çoktan seçmeli olarak, 2'nci kısımdaki ifadeler (kesinlikle katılıyorum/5'ten kesinlikle katılmıyorum/1'e uzanan) 5'li ölçek ile öğrencilere yöneltilmiştir.

Araştırmada kullanılan tüm ölçekler daha önce çeşitli araştırmalarda kullanıldığından, çalışmada ölçeklere sadece Doğrulayıcı Faktör Analizi (DFA) uygulanmıştır. Test edilen modellerin, toplanan veriler için uygunluğuna ilişkin istatistikî bilgiler sunan DFA sonuçları, uyum istatistiklerine göre değerlendirilmiştir. DFA uygulanırken ilişkisiz model, birincil seviye, ikincil seviye ve tek faktörlü model için uygulanmış ve aralarından en iyi uyum 
Girişimcilik Eğilimini Etkileyen Faktörlere İlişkin Çok Boyutlu Bir Analiz:

Orta Öğretimde Bir Araştırma

sonuçlarını veren model seçilmiştir (Meydan, Şeşen, 2011; 57). Analiz sonucunda ulaşılan değerler Tablo 4'te yer almaktadır. Değerler incelendiğinde birincil seviye DFA sonuçlarına göre modelin iyi uyum gösterdiği ifade edilebilir. DFA analizi sonucunda ulaşılan boyutların güvenilirlik analizi yapılmıştır. Araştırmanın girişimcilik eğilimine etki eden ifadelere ilişkin incelenen soruların ölçeğine göre güvenilirlik analizi Cronbach's Alpha değeri 0,856 olarak hesaplanmıştır. Bu değer, ölçeğin güvenilir olduğunu göstermektedir.

Tablo 4: Girişimcilik Eğilimi Ölçeği Birincil Seviye Doğrulayıcı Faktör Analizi Sonuçları

\begin{tabular}{|l|l|l|l|l|l|l|l|}
\hline MODEL & $\chi^{\mathbf{2}}$ & df & $\chi^{2} / \mathbf{d f}$ & RMSEA & CFI & GFI & AGFI \\
\hline & 3547,825 & 1027 & 3,455 & 0,041 & 0,819 & 0,901 & 0,887 \\
\hline
\end{tabular}

$\Delta X^{2}$ : Ki kare(CMIN) df: Degrees of Freedom; RMSEA:Root Mean Square Error of Approximation;CFI:Comparative Fit Index; GFI:Goodness of Fit Index;AGFI:Adjusted Goodness Fit Index.

\section{Örneklemin Girişimcilik Eğilim Düzeyleri}

Tüm örnekleme ilişkin girişimcilik eğilimi düzeyinin sonuçları Tablo 5'te verilmiştir. Bu tabloda, Azimli ve Rekabetçi Olma, Yeni iş Kurma Zorluğu, Yenilik Yaratma, Aile Desteği, Hümanizm, Başarı İhtiyacı, İçsel Kontrol Odağ1 yönünden tüm örneklemin ortalamasının yüksek olduğu; Riskten Kaçınma, Kendi İşini Kurma Fırsatı, Dışsal Kontrol Odağı özelliği yönünden ise, ortalamanın düşük olduğu görülmektedir. En düşük ortalamanın Riskten Kaçınma faktöründe $(2,67)$ en yüksek ortalamanın Aile Desteği faktöründe $(3,69)$ olduğu görülmektedir. Örneklemin, girişimcilik eğilim düzeyi yönünden ortalamasının 3,26 ve ortalamaların standart sapmasının 0,45432 olduğu görülmektedir. 
Tablo 5: Örneklemin Girişimcilik Eğilim Düzeyleri (N=1431, En az 1 En çok 5)

\begin{tabular}{|l|c|c|}
\hline \multicolumn{1}{|c|}{$\begin{array}{c}\text { Girişimcilik Ĕgilimi } \\
\text { Faktörleri }\end{array}$} & Ortalama & Standart sapma \\
\hline Azimli ve Rekabetçi Olma & 3,5990 &, 69600 \\
\hline Yeni iş Kurma Zorluğu & 2,9810 &, 78970 \\
\hline Yenilik Yaratma & 3,3205 &, 90595 \\
\hline Riskten Kaçınma & $\mathbf{2 , 6 7 9 1}$ & $\mathbf{8 1 5 2 8}$ \\
\hline Kendi İşini Kurma Fırsatı & 2,7927 &, 65792 \\
\hline Aile desteği & $\mathbf{3 , 6 9 3 5}$ & $\mathbf{9 5 1 9 0}$ \\
\hline Hümanizm & 3,6338 &, 93947 \\
\hline Başarı İhtiyacı & 3,4875 &, 66981 \\
\hline İçsel Kontrol Odağ1 & 3,6518 &, 81837 \\
\hline Dişsal Kontrol Odağı & 2,7701 &, 71243 \\
\hline Girişimcilik Eğilimi & $\mathbf{3 , 2 6 0 9}$ & $\mathbf{4 5 4 3 2}$ \\
\hline
\end{tabular}

\section{Girişimcilik Eğiliminin Cinsiyete Göre Farklılığı}

Bağımsız grupların t testi iki bağımsız grubun ortalamalarının birbirinden farklı olup olmadığını test etmek amacı ile kullanılan, istatistiksel analiz yöntemidir. Bu testin yapılabilmesi için karşılaştırılacak olan grupların birbirinden bağımsız olması (kız ve erkek gibi) ve bu gruplardan elde edilen ölçümlerin en az eşit aralıklı ölçek düzeyinde ölçülmüş olması gerekmektedir (Durmuş vd.,2013;118).

Cinsiyet ve girişimcilik eğilimi arasındaki ilişki, yukarıda tanımladığımız bağımsız gruplar $\mathrm{t}$ testine uymaktadır.

Girişimcilik eğiliminin ve girişimcilik eğiliminini etkileyen faktörlerin cinsiyete göre farklılığını tespit etmek için test edilecek hipotezler aşağıdaki gibidir;

Hla:Girişimcilik ĕgilimi, cinsiyete göre anlaml farklllk göstermektedir.

H1b:Girişimcilik eğilimini etkileyen faktörler, cinsiyete göre anlaml farklılık göstermektedir. 
Girişimcilik Eğilimini Etkileyen Faktörlere İlişkin Çok Boyutlu Bir Analiz:

Orta Öğretimde Bir Araştırma

Tablo 6:Cinsiyete Göre Girişimcilik Eğilimi ve Girişimcilik Eğilimini Etkileyen

Faktörlerin Tanımlayıcı t Testi Sonuçları

\begin{tabular}{|l|c|c|c|c|}
\hline \multicolumn{1}{|c|}{ Değişkenler } & t istatistik & $\begin{array}{c}\text { Serbestlik } \\
\text { Derecesi }\end{array}$ & $\begin{array}{c}\text { Anlamlılık } \\
\text { Derecesi }\end{array}$ & $\begin{array}{c}\text { Ortalama } \\
\text { Fark }\end{array}$ \\
\hline Azimli ve Rekabetçi Olma(f1) & 1,119 & 1429 &, 263 &, 04130 \\
\hline Yeni iş Kurma Zorluğu(f2) &,- 016 & 1416,714 &, 987 &,- 00068 \\
\hline Yenilik Yaratma(f3) & $-1,577$ & 1418,837 &, 115 &,- 07526 \\
\hline Riskten Kaçınma(f4) & $\mathbf{- 3 , 6 4 1}$ & $\mathbf{1 4 2 9}$ & $\mathbf{, 0 0 0}$ & $\mathbf{- , 1 5 6 8 0}$ \\
\hline Kendi İşini Kurma Fırsatı(f5) & $\mathbf{- 3 , 9 9 9}$ & $\mathbf{1 4 2 9}$ & $\mathbf{, 0 0 0}$ & $\mathbf{- , 1 3 8 8 5}$ \\
\hline Aile desteği(f6) & $\mathbf{3 , 5 7 6}$ & $\mathbf{1 4 2 9}$ & $\mathbf{, 0 0 0}$ & $\mathbf{1 7 9 8 8}$ \\
\hline Hümanizm(f7) & $\mathbf{2 , 0 2 3}$ & $\mathbf{1 4 2 9}$ & $\mathbf{, 0 4 3}$ &, $\mathbf{1 0 0 7 3}$ \\
\hline Başarı İhtiyacı(f8) &, 164 & 1429 &, 869 &, 00582 \\
\hline İçsel Kontrol Odağı(f9) & 1,384 & 1429 &, 167 &, 06007 \\
\hline Dişsal Kontrol Odağı(f10) & $-1,402$ & 1429 &, 160 &,- 05297 \\
\hline Girişimcilik Eğilimi &,- 152 & 1429 &, 879 &,- 00368 \\
\hline
\end{tabular}

Girişimcilik Eğilimini etkileyen "Riskten Kaçınma (f4)", "Kendi İşini Kurma Fırsatı (f5)", "Aile Desteği (f6)" ve "Hümanizm (f7)" faktörleri açısından cinsiyet itibariyle istatiksel olarak anlamlı fark vardır $(p<0,05)$. Diğer faktörler açısından cinsiyet itibariyle istatiksel olarak anlamlı fark yoktur (Tablo 6).

Girişimcilik eğilimi ile cinsiyet arasında istatistiksel olarak anlamlı fark yoktur.

Girişimcilik eğilimini etkileyen faktörler açısından cinsiyetin tanımlayıcı istatistiği Tablo 7'de sunulmuştur. 
Tablo 7: Girişimcilik Eğilimi ve Girişimcilik Eğilimini Etkileyen Faktörler Açısından Cinsiyetin Tanımlayıcı İstatistiği

\begin{tabular}{|c|c|c|c|c|c|}
\hline Faktörler & Cinsiyet & $\begin{array}{l}\text { Gözlem } \\
\text { Sayısı }\end{array}$ & Ortalama & Standart Sapma & $\begin{array}{c}\text { Standart } \\
\text { Ortalama } \\
\text { Hatası }\end{array}$ \\
\hline \multirow{2}{*}{$\begin{array}{l}\text { Azimli ve Rekabetçi } \\
\text { Olma(f1) }\end{array}$} & Kadın & 775 & 3,6179 & ,71685 &, 02575 \\
\hline & Erkek & 656 & 3,5766 & ,67039 & ,02617 \\
\hline \multirow{2}{*}{$\begin{array}{l}\text { Yeni iş Kurma } \\
\text { Zorluğu(f2) }\end{array}$} & Kadın & 775 & 2,9806 & ,81607 &, 02931 \\
\hline & Erkek & 656 & 2,9813 & ,75799 & ,02959 \\
\hline \multirow{2}{*}{ Yenilik Yaratma(f3) } & Kadın & 775 & 3,2860 & ,93872 & ,03372 \\
\hline & Erkek & 656 & 3,3613 &, 86457 & ,03376 \\
\hline \multirow{2}{*}{ Riskten Kaçınma(f4) } & Kadın & 775 & 2,6072 & ,80736 & ,02900 \\
\hline & Erkek & 656 & 2,7640 &, 81702 & ,03190 \\
\hline \multirow{2}{*}{$\begin{array}{l}\text { Kendi İşini Kurma } \\
\text { Fursatı(f5) }\end{array}$} & Kadın & 775 & 2,7290 &, 65328 &, 02347 \\
\hline & Erkek & 656 & 2,8679 & ,65595 &, 02561 \\
\hline \multirow{2}{*}{ Aile desteği(f6) } & Kadın & 775 & 3,7759 & ,95662 &, 03436 \\
\hline & Erkek & 656 & 3,5960 & ,93772 & ,03661 \\
\hline \multirow{2}{*}{ Hümanizm(f7) } & Kadın & 775 & 3,6800 & ,93879 &, 03372 \\
\hline & Erkek & 656 & 3,5793 & ,93807 & ,03663 \\
\hline \multirow{2}{*}{ Başarı İhtiyacı(f8) } & Kadın & 775 & 3,4901 & ,68531 &, 02462 \\
\hline & Erkek & 656 & 3,4843 & ,65153 &, 02544 \\
\hline \multirow{2}{*}{ İçsel Kontrol Odağı(f9) } & Kadın & 775 & 3,6794 &, 81616 &, 02932 \\
\hline & Erkek & 656 & 3,6193 & ,82040 &, 03203 \\
\hline \multirow{2}{*}{$\begin{array}{l}\text { Dişsal Kontrol } \\
\text { Odağı(f10) }\end{array}$} & Kadın & 775 & 2,7458 & ,72399 & ,02601 \\
\hline & Erkek & 656 & 2,7988 & ,69799 &, 02725 \\
\hline \multirow{2}{*}{ Girişimcilik Eğilimi } & Kadın & 775 & 3,2592 & ,46666 &, 01676 \\
\hline & Erkek & 656 & 3,2629 & ,43965 & ,01717 \\
\hline
\end{tabular}

Tablo 7'ye bakıldığında; cinsiyet itibariyle "Riskten Kaçınma (f4)" ve "Kendi İşini Kurma Fırsatı (f5)" faktörleri açısından kadın öğrencilerin ortalamalarının erkek öğrencilere göre daha yüksek olduğu, "Aile Desteği (f6)" ve "Hümanizm (f7)" faktörleri açısından ise erkek öğrencilerin ortalamalarının kadın öğrencilere göre daha yüksek olduğu görülmüştür. 
Girişimcilik Eğilimini Etkileyen Faktörlere İlişkin Çok Boyutlu Bir Analiz:

Orta Öğretimde Bir Araştırma

\section{Girişimcilik Eğiliminin Öğrencilerin Öğrenim Gördükleri Okullara Göre Farklılığı}

Girişimcilik eğiliminin ve girişimcilik eğiliminini etkileyen faktörlerin, öğrencilerin öğrenim gördükleri okullara göre farklılığını tespit etmek için test edilecek hipotezler aşağıdaki gibidir;

H2a:Girişimcilik eğilimi, öğrencilerin öğrenim gördükleri okullara göre anlamlı farklllık göstermektedir.

H2b:Girişimcilik eğilimini etkileyen faktörler, öğrencilerin ögrenim gördükleri okullara göre anlamlı farklllık göstermektedir.

Tablo 8: Öğrencilerin Öğrenim Gördükleri Okullara Göre Girişimcilik Eğilimi ve Girişimcilik Eğilimini Etkileyen Faktörlerin ANOVA Testi Sonuçları

\begin{tabular}{|c|c|c|c|c|c|c|}
\hline \multirow{2}{*}{ Faktörler } & \multicolumn{2}{|c|}{$\begin{array}{l}\text { Test of Homogeneity of } \\
\text { Variances }\end{array}$} & \multicolumn{2}{|l|}{ ANOVA } & \multirow{2}{*}{\multicolumn{2}{|c|}{$\begin{array}{l}\text { Welch } \\
\text { Brown-Forsythe } \\
\text { Anlamlilik } \\
\text { Derecesi }\end{array}$}} \\
\hline & $\begin{array}{l}\text { Levene } \\
\text { İstatistiği }\end{array}$ & $\begin{array}{l}\text { Anlamlilik } \\
\text { Derecesi }\end{array}$ & F Değeri & $\begin{array}{l}\text { Anlamlilik } \\
\text { Derecesi }\end{array}$ & & \\
\hline $\begin{array}{l}\text { Azimli ve Rekabetçi } \\
\text { Olma(f1) }\end{array}$ & 1,719 &, 143 & 2,148 & ,073 & \multicolumn{2}{|c|}{ - } \\
\hline $\begin{array}{l}\text { Yeni iş Kurma } \\
\text { Zorluğu(f2) }\end{array}$ & ,330 & ,858 & 5,013 & ,001 & \multicolumn{2}{|c|}{ - } \\
\hline $\begin{array}{l}\text { Yenilik } \\
\text { Yaratma(f3) }\end{array}$ & 1,497 & ,201 & 3,067 & ,016 & \multicolumn{2}{|c|}{ - } \\
\hline $\begin{array}{l}\text { Riskten } \\
\text { Kaçınma(f4) }\end{array}$ & 3,506 & ,007 & - & - & ,000 & ,001 \\
\hline $\begin{array}{l}\text { Kendi İşini Kurma } \\
\text { Fırsatı(f5) }\end{array}$ & 1,494 & ,201 & 2,178 & ,069 & \multicolumn{2}{|c|}{-} \\
\hline Aile Desteği(f6) & 4,550 & ,001 & - & - & ,881 & ,892 \\
\hline Hümanizm(f7) & 2,592 & 035 & - & - & ,314 & ,308 \\
\hline Başarı İhtiyacı(f8) & 1,229 & ,296 & 2,720 & ,028 & \multicolumn{2}{|c|}{-} \\
\hline $\begin{array}{ll}\text { İçsel } & \text { Kontrol } \\
\text { Odağı(f9) } & \end{array}$ & 3,181 & ,013 & - & - & ,066 & ,046 \\
\hline $\begin{array}{l}\text { Dişsal Kontrol } \\
\text { Odağı(f10) }\end{array}$ & ,974 & ,421 & 7,271 & ,000 & \multicolumn{2}{|c|}{ - } \\
\hline Girişimcilik Eğilimi & 2,713 & 029 & - & - & 093 &, 086 \\
\hline
\end{tabular}


Levene test sonucunda; "Yeni İş Kurma Zorluğu (f2)", "Yenilik Yaratma (f3)", "Riskten Kaçınma (f4)", "Başarı İhtiyacı (f8)" ve "Dışsal Kontrol Odağ (f10)" ( $p<0,05)$ grup varyanslarının homojen olmadığı görülmüştür.

Yapilan Anova, Welch ve Brown-Forsythe testleri anlamlilik derecesine bakıldığında girişimcilik eğilimini etkileyen "Yeni İş Kurma Zorluğu (f2)" "Yenilik Yaratma (f3)", "Riskten Kaçınma (f4)", "Başarı İhtiyacı (f8)", ve "Dışsal Kontrol Odağ (f10)" faktörleri açısından öğrencilerin öğrenim gördükleri okullar itibariyle istatiksel olarak anlamlı bir fark vardır. Diğer faktörler açısından öğrencilerin öğrenim gördükleri okullar itibariyle istatiksel olarak anlamlı bir fark yoktur (Tablo 8).

Girişimcilik eğilimi ile öğrencilerin öğrenim gördükleri okullar arasında istatistiksel olarak anlamlı bir fark yoktur.

Girişimcilik eğilimi ve girişimcilik eğilimini etkileyen faktörler açısından öğrencilerin öğrenim gördükleri okulların tanımlayıcı istatistiği Tablo 9'da sunulmuştur.

Tablo 9: Girişimcilik Eğilimi ve Girişimcilik Eğilimini Etkileyen Faktörler Açısından Öğrencilerin Öğrenim Gördükleri Okulların Tanımlayıcı İstatistiği

\begin{tabular}{|c|c|c|c|c|c|}
\hline Faktör & Değişkenler & $\mathbf{N}$ & Ortalama & $\begin{array}{c}\text { Standart } \\
\text { Sapma }\end{array}$ & $\begin{array}{c}\text { Standart } \\
\text { Hata }\end{array}$ \\
\hline \multirow{6}{*}{$\begin{array}{l}\text { Yeni İş } \\
\text { Kurma } \\
\text { Zorluğu } \\
\text { (f2) }\end{array}$} & $\begin{array}{l}\text { Teknik ve Endüstri } \\
\text { Meslek Lisesi }\end{array}$ & 357 & 3,0658 & ,78648 & ,04162 \\
\hline & İmam Hatip Lisesi & 295 & 2,8271 &, 77714 &, 04525 \\
\hline & Fen Lisesi & 110 & 3,0909 & ,81888 &, 07808 \\
\hline & Anadolu Lisesi & 492 & 2,9573 & ,77788 & ,03507 \\
\hline & Ticaret Meslek Lisesi & 177 & 3,0636 & ,79584 & ,05982 \\
\hline & Toplam & 1431 & 2,9810 & ,78970 & ,02088 \\
\hline \multirow{6}{*}{$\begin{array}{l}\text { Yenilik } \\
\text { Yaratma } \\
\text { (f3) }\end{array}$} & $\begin{array}{l}\text { Teknik ve Endüstri } \\
\text { Meslek Lisesi }\end{array}$ & 357 & 3,2138 & ,88476 & ,04683 \\
\hline & İmam Hatip Lisesi & 295 & 3,3605 & ,95990 & ,05589 \\
\hline & Fen Lisesi & 110 & 3,1758 & ,90046 & ,08586 \\
\hline & Anadolu Lisesi & 492 & 3,3672 & ,88114 & ,03972 \\
\hline & Ticaret Meslek Lisesi & 177 & 3,4294 & ,90604 & ,06810 \\
\hline & Toplam & 1431 & 3,3205 & ,90595 & ,02395 \\
\hline
\end{tabular}


Girişimcilik Eğilimini Etkileyen Faktörlere İlişkin Çok Boyutlu Bir Analiz:

Orta Öğretimde Bir Araştırma

\begin{tabular}{|c|c|c|c|c|c|}
\hline Faktör & Değișkenler & $\mathbf{N}$ & Ortalama & $\begin{array}{l}\text { Standart } \\
\text { Sapma }\end{array}$ & $\begin{array}{c}\text { Standart } \\
\text { Hata }\end{array}$ \\
\hline \multirow{6}{*}{$\begin{array}{l}\text { Riskten } \\
\text { Kaçınma } \\
\text { (f4) }\end{array}$} & $\begin{array}{l}\text { Teknik ve Endüstri } \\
\text { Meslek Lisesi }\end{array}$ & 357 & 2,8034 &, 82720 & 04378 \\
\hline & İmam Hatip Lisesi & 295 & 2,5207 & ,76404 &, 04448 \\
\hline & Fen Lisesi & 110 & 2,6709 & ,85867 & ,08187 \\
\hline & Anadolu Lisesi & 492 & 2,6821 &, 77144 &, 03478 \\
\hline & Ticaret Meslek Lisesi & 177 & 2,6893 & ,92242 & 06933 \\
\hline & Toplam & 1431 & 2,6791 & ,81528 &, 02155 \\
\hline \multirow{6}{*}{$\begin{array}{l}\text { Başarı } \\
\text { İhtiyacı } \\
\text { (f8) }\end{array}$} & $\begin{array}{l}\text { Teknik ve Endüstri } \\
\text { Meslek Lisesi }\end{array}$ & 357 & 3,3886 & ,66955 & ,03544 \\
\hline & İmam Hatip Lisesi & 295 & 3,5157 & ,69098 &, 04023 \\
\hline & Fen Lisesi & 110 & 3,5597 & ,59080 &, 05633 \\
\hline & Anadolu Lisesi & 492 & 3,5186 & ,65749 & ,02964 \\
\hline & Ticaret Meslek Lisesi & 177 & 3,5085 & ,70082 & ,05268 \\
\hline & Toplam & 1431 & 3,4875 & 66981 & ,01771 \\
\hline \multirow{6}{*}{$\begin{array}{l}\text { Dişsal } \\
\text { Kontrol } \\
\text { Odağı } \\
\text { (f10) }\end{array}$} & $\begin{array}{l}\text { Teknik ve Endüstri } \\
\text { Meslek Lisesi }\end{array}$ & 357 & 2,8852 & ,70137 & ,03712 \\
\hline & İmam Hatip Lisesi & 295 & 2,6723 &, 72150 & ,04201 \\
\hline & Fen Lisesi & 110 & 2,5727 & ,75099 &, 07160 \\
\hline & Anadolu Lisesi & 492 & 2,7473 & ,67689 &, 03052 \\
\hline & Ticaret Meslek Lisesi & 177 & 2,8870 &, 74118 &, 05571 \\
\hline & Toplam & 1431 & 2,7701 &, 71243 & ,01883 \\
\hline \multirow{6}{*}{$\begin{array}{l}\text { Girişimcilik } \\
\text { Eğilimi }\end{array}$} & $\begin{array}{l}\text { Teknik ve Endüstri } \\
\text { Meslek Lisesi }\end{array}$ & 357 & 3,2677 & ,48576 & 02571 \\
\hline & İmam Hatip Lisesi & 295 & 3,2267 & ,47342 & ,02756 \\
\hline & Fen Lisesi & 110 & 3,2004 & ,38356 &, 03657 \\
\hline & Anadolu Lisesi & 492 & 3,2642 & ,41539 & ,01873 \\
\hline & Ticaret Meslek Lisesi & 177 & 3,3324 &, 49336 &, 03708 \\
\hline & Toplam & 1431 & 3,2609 &, 45432 & ,01201 \\
\hline
\end{tabular}


Tablo 9'a bakıldığında; Öğrencilerin Öğrenim Gördükleri Okullar itibariyle "Yeni İş Kurma Zorluğu (f2)" faktörü açısından "Fen Lisesi", "Teknik ve Endüstri Meslek Lisesi" ve "Ticaret Meslek Lisesi” nde okuyan öğrencilerin ortalamalarının "İmam Hatip Lisesi"nde okuyan öğrencilere göre daha yüksek olduğu; "Yenilik Yaratma (f3)" faktörü açısından "Ticaret Meslek Lisesi" nde okuyan öğrencilerin ortalamalarının "Fen Lisesi" nde okuyan öğrencilere göre daha yüksek olduğu; "Riskten Kaçınma (f4)" faktörü açısından "Teknik ve Endüstri Meslek Lisesi" nde okuyan öğrencilerin ortalamalarının "İmam Hatip Lisesi”nde okuyan öğrencilere göre daha yüksek olduğu; "Başarı İhtiyacı (f8)" faktörü açısından "Fen Lisesi” ve "Anadolu Lisesi" nde okuyan öğrencilerin ortalamalarının "Teknik ve Endüstri Meslek Lisesi" nde okuyan öğrencilere göre daha yüksek olduğu; "Dışsal Kontrol Odağı (f10)" faktörü açısından "Teknik ve Endüstri Meslek Lisesi” ve "Ticaret Meslek Lisesi”nde okuyan öğrencilerin ortalamalarının "Fen Lisesi”"nde okuyan öğrencilere göre daha yüksek olduğu tespit edilmiştir.

\section{Girişimcilik Eğiliminin Öğrencilerin Girişimcilik Dersi Alma Durumuna Göre Farklılı̆̆}

Girişimcilik eğiliminin ve girişimcilik eğiliminini etkileyen faktörlerin, öğrencilerin girişimcilik dersi alma durumuna göre farklılığını tespit etmek için test edilecek hipotezler aşağıdaki gibidir;

H3a:Girişimcilik eğilimi, öğrencilerin girişimcilik dersi alma durumuna göre anlaml farklılık göstermektedir.

H3b:Girişimcilik eğilimini etkileyen faktörler, öğrencilerin girişimcilik dersi alma durumuna göre anlaml farklılı göstermektedir. 
Girişimcilik Eğilimini Etkileyen Faktörlere İlişkin Çok Boyutlu Bir Analiz:

Orta Öğretimde Bir Araştırma

Tablo 10: Girişimcilik Eğilimi ve Girişimcilik Eğilimini Etkileyen Faktörler

Açısından Öğrencilerin Girişimcilik Dersi Alma Durumunun T Testi Sonuçları

\begin{tabular}{|l|c|c|c|c|}
\hline \multicolumn{1}{|c|}{ Değişkenler } & t istatistik & $\begin{array}{c}\text { Serbestlik } \\
\text { Derecesi }\end{array}$ & $\begin{array}{c}\text { Anlamlılık } \\
\text { Derecesi }\end{array}$ & $\begin{array}{c}\text { Ortalama } \\
\text { Fark }\end{array}$ \\
\hline Azimli ve Rekabetçi Olma(f1) & 1,025 & 1359 &, 306 &, 05232 \\
\hline Yeni iş Kurma Zorluğu(f2) & 1,130 & 1359 &, 259 &, 06603 \\
\hline Yenilik Yaratma(f3) & 1,066 & 1359 &, 287 &, 07196 \\
\hline Riskten Kaçınma(f4) & 1,556 & 1359 &, 120 &, 09349 \\
\hline Kendi İşini Kurma Fırsatı(f5) & 1,868 & 1359 &, 062 &, 09077 \\
\hline Aile Desteği(f6) &, 206 & 1359 &, 837 &, 01456 \\
\hline Hümanizm(f7) & $\mathbf{2 , 0 4 4}$ & $\mathbf{1 3 5 9}$ & $\mathbf{, 0 4 1}$ &, $\mathbf{1 4 1 5 7}$ \\
\hline Başarı İhtiyacı(f8) &, 578 & 1359 &, 564 &, 02857 \\
\hline İçsel Kontrol Odakğı(f9) & 1,129 & 1359 &, 259 &, 06795 \\
\hline Dışsal Kontrol Odağı(f10) & $\mathbf{2 , 6 0 4}$ & $\mathbf{2 8 5 , 8 6 4}$ & $\mathbf{, 0 1 0}$ & $\mathbf{1 4 7 3 6}$ \\
\hline Girişimcilik Eğilimi & $\mathbf{2 , 3 2 3}$ & $\mathbf{1 3 5 9}$ & $\mathbf{, 0 2 0}$ & $\mathbf{, 0 7 7 4 6}$ \\
\hline
\end{tabular}

Girişimcilik Eğilimini etkileyen "Hümanizm (f7)" ve "Dışsal Kontrol Odağı (f10)" faktörleri açısından girişimcilik dersi alınması itibariyle istatiksel olarak anlamlı fark vardır $(\mathrm{p}<0,05)$. Diğer faktörler açısından girişimcilik dersi alınması itibariyle istatiksel olarak anlamlı fark yoktur (Tablo 10).

Girişimcilik eğilimi ile girişimcilik dersi alınması arasında istatistiksel olarak anlamlı fark vardır.

Girişimcilik eğilimini ve girişimcilik eğilimini etkileyen faktörler açısından girişimcilik dersi alınmasının tanımlayıcı istatistiği Tablo 11'de sunulmuştur. 
Tablo 11: Girişimcilik Eğilimi ve Girişimcilik Eğilimini Etkileyen Faktörler Açısından Öğrencilerin Girişimcilik Dersi Almasının Tanımlayıcı İstatistiği

\begin{tabular}{|c|c|c|c|c|c|}
\hline Faktörler & Cinsiyet & $\begin{array}{c}\text { Gözlem } \\
\text { Sayısı }\end{array}$ & Ortalama & $\begin{array}{c}\text { Standart } \\
\text { Sapma }\end{array}$ & $\begin{array}{c}\text { Standart } \\
\text { Ortalama } \\
\text { Hatası }\end{array}$ \\
\hline \multirow{2}{*}{ Azimli ve Rekabetçi Olma(f1) } & Kadin & 775 & 3,6179 &, 71685 &, 02575 \\
\hline & Erkek & 656 & 3,5766 & 67039 &, 02617 \\
\hline \multirow{2}{*}{ Yeni iş Kurma Zorluğu(f2) } & Kadın & 775 & 2,9806 & ,81607 &, 02931 \\
\hline & Erkek & 656 & 2,9813 &, 75799 & ,02959 \\
\hline \multirow{2}{*}{ Yenilik Yaratma(f3) } & Kadın & 775 & 3,2860 & ,93872 &, 03372 \\
\hline & Erkek & 656 & 3,3613 &, 86457 & 03376 \\
\hline \multirow{2}{*}{ Riskten Kaçınma(f4) } & Kadın & 775 & 2,6072 &, 80736 &, 02900 \\
\hline & Erkek & 656 & 2,7640 &, 81702 & 03190 \\
\hline \multirow{2}{*}{ Kendi İşini Kurma Fırsatı(f5) } & Kadın & 775 & 2,7290 &, 65328 &, 02347 \\
\hline & Erkek & 656 & 2,8679 &, 65595 &, 02561 \\
\hline \multirow{2}{*}{ Aile Desteği(f6) } & Kadın & 775 & 3,7759 &, 95662 &, 03436 \\
\hline & Erkek & 656 & 3,5960 & ,93772 & ,03661 \\
\hline \multirow{2}{*}{ Hümanizm(f7) } & Kadın & 775 & 3,6800 &, 93879 &, 03372 \\
\hline & Erkek & 656 & 3,5793 & ,93807 & ,03663 \\
\hline \multirow{2}{*}{ Başarı İhtiyacı(f8) } & Kadın & 775 & 3,4901 &, 68531 &, 02462 \\
\hline & Erkek & 656 & 3,4843 &, 65153 &, 02544 \\
\hline \multirow{2}{*}{ İçsel Kontrol Odağı(f9) } & Kadın & 775 & 3,6794 &, 81616 &, 02932 \\
\hline & Erkek & 656 & 3,6193 & ,82040 & ,03203 \\
\hline \multirow{2}{*}{ Dışsal Kontrol Odağı(f10) } & Kadın & 775 & 2,7458 &, 72399 & ,02601 \\
\hline & Erkek & 656 & 2,7988 & ,69799 &, 02725 \\
\hline \multirow{2}{*}{ Girişimcilik Eğilimi } & Kadın & 775 & 3,2592 & ,46666 &, 01676 \\
\hline & Erkek & 656 & 3,2629 & ,43965 & ,01717 \\
\hline
\end{tabular}

Tablo 11'e bakıldığında; "Hümanizm (f7)", "Dışsal Kontrol Odağı (f10)" faktörleri ve "Girişimcilik Eğilimi” açısından girişimcilik dersi alan öğrencilerin ortalamalarının, girişimcilik dersi almayan öğrencilere göre daha yüksek olduğu görülmüştür.

\section{Sonuç ve Değerlendirme}

Literatürde yapılmış olan çalışmalar girişimciliğin gerek ekonomide gerek sosyal alanda bireylere ve toplumlara pozitif yönde katkılar getirdiğini 
Girişimcilik Eğilimini Etkileyen Faktörlere İlişkin Çok Boyutlu Bir Analiz:

Orta Öğretimde Bir Araştırma

belirtmektedir. Adeta ülkelerin lokomatifi durumda olan girişimciliğin, eğitiminin verilmesinin de önemi görülmektedir. Etkin girişimciler sayesinde piyasaya katılan yeni işletmeler ülke ekonomilerine yön verdikleri gibi işsizlik oranınında ciddi anlamda düşüşe sebep olmaktadır. Dünyada artan ve gelişen teknolojik buluşlar toplumlar ve bireyler arasındaki görsel ve işitsel etkileşimi kaçınılmaz hale getirmiştir. Bilginin hızla yayıldığı bu zamanda edinilen her bilgi yeni fikirler yaratmakta ve bunun neticesinde de yeni girişimciler doğmaktadır. Ancak ülkeler, yeni doğan bu girişimcilere gerekli yasal ve ekonomik koşulları uygun şartlar altında girişimcilere sunmalıdır. En başta ise ülkenin geleceğinin garantisi ve iktisadi yönden omurgası olacak girişimci genç bireylere, hangi özelliklerde ve nasıl girişimci olunabileceği ile ilgili olarak gerekli eğitim verilmelidir. Toplumsal olarak kültürel farklılıkların neticesinde bireylerin girişimci ve girişimcilik eğiliminin değişik derecelerde olduğu bir gerçektir. Girişimcilik felsefesinin özgürlükçü bireylerde daha yaygın olduğu ve girişimcilik denemelerinde daha başarılı oldukları görülmektedir. Girişimci bireyler yaratmada toplumda özgürlükçü bir yaklaşım sergilemenin gerekliliği önemliyken, girişimcilik denemelerinde başarısız olan bireyleri bu konuda teşvik etmek ve kabul edilebilir riskleri tekrar alabilecekleri şekilde pozitif yönde motive etmek bir o kadar önemlidir.

Girişimcilik eğitiminin lise düzeyinden başlaması gerektiği fikrini savunan uzmanlar ayrıca girişimciliğin öğretilebildiğine de inanmaktadır. Özellikle Türk insanı gerçek başarı hikâyelerinden, girişimciliğin olumlu sonuçlarını kendi gözleriyle görmekten etkilenmeleri sebebiyle Avrupa Birliği ülkelerinde uygulanan teorik girişimcilik eğitimi yerine Türkiye'de daha çok pratik girişimciliğin başarılı olacağı tezi savunulmaktadır. Genç nüfus oranının yüksek olduğu Türkiye'de potansiyel genç girişimcileri tespit ve teşvik etmek ekonomik istikrar için bir gerekliliktir. Bundan dolayı gerek lise gerek Üniversite eğitiminde gençlerin girişimcilik eğilimlerinin artırılması önem kazanmaktadır.

Seçilmiş lise öğrencilerinin girişimcilik eğilimlerini etkileyen faktörleri tespit etmeyi ve öne çıkan bazı demografik özelliklerin bu faktörlere etkisini araştırmayı amaçlayan bu çalışma 9'uncu ve 10'uncu sınıf öğrencilerine yüz yüze anket yöntemi kullanılarak uygulanmıştır.

Yapılmış olan literatür incelemesi ve analizler sonucunda girişimcilik eğilimine etki eden faktörlerin genel olarak: azimli ve rekabetçi olma, yeni iş 
kurma güçlüğ̈̈, yenilik yaratma, riskten kaçınma, kendi işini kurma firsatı ve çalışma, aile desteği, hümanizm, iç ve dış kontrol odağı ve başarı ihtiyacı faktörlerinin olduğu tespit edilmiştir.

Ayrıca öğrencilerin girişimcilik eğilimi açısından cinsiyetin etkisinin olmamasını, toplumdaki ekonomik rolde kadının da yerinin olması gerekliliği ve erkek karşısında maddi özgürlüğünü sağlama düşüncesi etkilemiş olabilir. Öğrencilerin öğrenim gördükleri okullar ile girişimcilik eğilimi arasındaki ilişkiye bakıldığında, her ne kadar öğrencilerin öğrenim gördükleri okullar ile girişimcilik eğilimi arasında anlamlı bir fark bulunamamış olsa da, "Ticaret Meslek Lisesi" öğrencilerinin girişimcilik eğilim ortalamalarının "İmam Hatip Lisesi” öğrencilerinden daha yüksek olduğu görülmüsştür. Bu sonuç ile Ticaret Meslek Liselerinin kuruluş amacının: ekonomik ve sektörel gelişmelere paralel olarak ülkemizin ticaret, maliye, pazarlama, muhasebecilik, büro hizmetleri, bankacıllk, kooperatifçilik, sigortacıllk, borsa hizmetleri, sekreterlik, gibi alanlarda kamu ve özel sektör kuruluşlarında görev alacak veya kendi başına iş yapacak vasıflı, nitelikli ara eleman ihtiyacını karşılamak olduğundan, diğer okullara nazaran girişimcilik eğiliminin daha yüksek olduğu söylenebilir. Girişimcilik dersi alan öğrencilerin, bu dersi almayan diğer öğrencilere nazaran girişimcilik eğiliminin yüksek olduğu tespit edilmiştir. Bu sonuç ile lise öğreniminde girişimcilik dersi almanın, bireylerin girişimcilik eğilimine pozitif yönde katkı sağladığı söylenebilir.

Refahın ön planda olduğu günümüzde, girişimci bireylere her zamankinden daha çok ihtiyacımız bulunmaktadır. Bu girişimci bireylerin ihtiyaç duyduğu özellikleri ve kültürü oluşturmanın temeli ise lise eğitimine girişimcilik derslerinin eklenmesi ve girişimci ruhun öğrencilere kazandırılması ile mümkün olabilecektir.

Sonuç itibari ile yapılmış olan bu çalışma; ileride yapılabilecek akademik çalışmalara 1şık tutacaktır. Gelecekte yapılacak çalışmalarda; özellikle bireylere özgür ruh ve özgüven kazandırabilecek kültürel olgular ile girişimcilik eğilimi arasındaki ilişkiler ve tanımlayıcı/görüşme yöntemi ile deneklerin girişimcilik ile ilgili durum ve düşünceleri analiz edilmelidir. 
Girişimcilik Eğilimini Etkileyen Faktörlere İlişsin Çok Boyutlu Bir Analiz:

Orta Öğretimde Bir Araştırma

\section{Extended Summary}

\section{Introduction}

The aim of this study is to investigate the entrepreneurial tendencies of high school 3 and 4th grade students in Ankara, to determine the factors affecting these trends and to examine the effects of family environment, personal characteristics, age, gender, demographic characteristics and their effects on these factors. This research; (20 in total), 1431 high schools from $3 \mathrm{rd}$ and 4 th grade in Anatolian High School, Imam Hatip High School, Science High School, Commerce Vocational High School, Technical and Industrial Vocational High School and Girls Vocational High School face-to-face survey method.

\section{Theoretical Framework}

\section{Entrepreneurship and Entrepreneurship Tendency}

Schumpeter, who is one of the most important specialists in the definition of entrepreneurship, is one of the first researchers to emphasize the concept of "innovation". Entrepreneurship is defined as innovation activities bearing economic value for business purposes (Brockhaus and Horwitz, 1986: 25). Hisrich (1985) described entrepreneurship as "a process and this process is getting money and personal satisfaction with various risks" (Erdoğmuş, 2007). When considered in this framework, it seems that the initiator's "need for success" dimension has been emphasized. According to Frank Knight, entrepreneurialism is inherently subject to real uncertainty as well as undertaking certain risks (Praag and Mirjam, 1999: 147, 322). When dealt with in this framework, the "risk taking" dimension of the entrepreneur seems to be emphasized. One of the most important factors affecting being an entrepreneur is the family factor. The main motivational factors of the way the family is raised by the family since childhood, the family support in their decisions, and the entrepreneurial endorsement of the perception of one's entrepreneurship by the family. There are various opinions in the literature on internal and external control orientation. Brockhaus and Horwitz control focus (Locus of Control); (Brockhaus and Horwitz, 1986: 25). This is the situation in which people perceive events that occur in their lives or their consequences as selfcontrol or outside their control. 


\section{The Importance of Entrepreneurship in terms of Economic and Social Development}

The place of entrepreneurship in economic development is directly related to the existence and qualities of the entrepreneurial ecosystem in the economy in which it operates. The concept of entrepreneurial ecosystem is often used in economies where the entrepreneurial phenomenon has developed, but it is the answer to the question "How is an entrepreneurial economy?" In terms of content. The innovation element at the core of entrepreneurship requires a development for human resources to be used at an adequate level, which promotes the social level of society (education, culture, language, etc.).

The researchers used religion, race, social environment, social prejudices, historical conditions, ethnic structure, and so on. (eg Verheul, 2003), which are factors that affect entrepreneurship. Max Weber first mentioned the role of nonprofit factors in entrepreneurship. The social aspect of Weber's model is defined as the "Protestant Work Ethic". From here it is considered as an important variable in explaining cultural interventional activities.

\section{Characteristics of Entrepreneur}

There are various opinions about the characteristics of entrepreneurs. These qualities can be distinguished according to their qualities by birth or later acquirement or by psychological and social based perspectives.

\section{Entrepreneurship Education in Turkey}

Although not widespread entrepreneurship education has been given secondary and higher education in Turkey.

Turkey has added Leonardo Da Vinci and Socrates programs which European Union opened to increase professional education, the amount of qualified labour force and entrepreneurship to it's education in the purpose of educating the peaple from different ages and jobs since the April of 2004 (Küçüktekin, 2006:8283).

Entrepreneurship-oriented EU projects are carried out in primary and secondary schools (Turkey Entrepreneurship Strategy and Action Plan 2014-2016, 2013: 83). 
Girişimcilik Eğilimini Etkileyen Faktörlere İlişkin Çok Boyutlu Bir Analiz:

Orta Öğretimde Bir Araştırma

\section{Research}

\section{Purpose and Method of Research}

The main purpose of this study is; selected high school students; to find out whether they have entrepreneurial tendencies at different levels, to identify the factors that affect entrepreneurial tendencies, and if there are factors that affect the tendency of entrepreneurship, it is a more meaningful difference and to investigate the relation between the prominent demographics and these factors.

In order to measure entrepreneurship tendency, Doğan's determination and competitiveness, the difficulty of establishing new business, innovation, risk avoidance, opportunity and work, to establish self-employment, family support and hümanism factor scale; McClelland's need for achievement factor scale published by Ucok and Rotter's control focus factor scale were used.

\section{Population and Sample}

The research was conducted in the form of questionnaire form for the students of 3 rd grade ( 934 students) and 4 th grade (497 students) in 7 Anatolian High Schools, 3 Science High Schools, 4 Imam Hatip High Schools and 6 Vocational High Schools. Within the scope of the study, a total of 1595 questionnaires were distributed to high school students in 3rd and 4th grade in different high schools and 1431 questionnaires were included in the evaluation.

\section{Analyzes and Findings}

According to the results of the analysis made to determine the adequacy of the sample included in the study; The KMO value was found to be 0.821 . The fact that the BMD test is close to 1 indicates that the survey represents the main mass. The significance of the Bartlett test is $p=0.00$, indicating that the sample is adequately tested and that significant factors can be obtained from the research data.

Cronbach's Alpha value was calculated to be 0.856 according to the scale of the questionnaires of the questionnaires affecting the entrepreneurship tendency of the research. This value indicates that your scale is reliable. 


\section{Entrepreneurship Trends in the Sample}

The average of the whole sample is high in terms of Perseverance and Competitiveness, Challenge of Establishing New Business, Innovation Creation, Family Support, Humanism, Success Needs and Internal Control Orientation and the average is low in terms of Risktan Avoidance, Self Establishment Opportunity, External Control Locality. The lowest average is found in the Risktan Avoidance factor (2.67) and the highest average is in the Family Support factor (3.69). It is seen that the sample has an average of 3.26 and a standard deviation of 0.45432 in terms of entrepreneurial propensity level.

\section{Differences of Entrepreneurship Trend by Gender}

Hypotheses to be tested to determine the sex-specific differences in entrepreneurial tendencies and the factors that influence entrepreneurial tendencies are as follows;

Hla: Entrepreneurship tendency differs according to sex.

HIb: Factors affecting entrepreneurship tendency differ according to sex.

There is no statistically significant difference between entrepreneurship tendency and gender.

\section{Differences in Entrepreneurship Trends by Schools}

The hypotheses to be tested to determine the differences in entrepreneurial propensity and entrepreneurial tendencies of the schools compared to the schools where the students have studied are as follows;

H2a: Entrepreneurship tendency differs according to the schools in which the students have studied.

H2b: Factors influencing entrepreneurship tendency differ according to the schools in which the students have studied.

There is no statistically significant difference between the entrepreneurial tendency and the Schools of the Students. 
Girişimcilik Eğilimini Etkileyen Faktörlere İlişkin Çok Boyutlu Bir Analiz:

Orta Öğretimde Bir Araştırma

\section{Difference of Entrepreneurship Trend by Students' Entrepreneurship Course Status}

The hypotheses to be tested to determine the differences in entrepreneurial propensity and entrepreneurial tendencies in order to determine the difference of students according to the level of entrepreneurship lesson taking are as follows;

H3a: The entrepreneurship tendency differs according to the entrepreneurship lessons of the students.

H3b: Factors affecting the tendency of entrepreneurship differ according to the entrepreneurship lessons of the students.

There is a statistically significant difference between entrepreneurship tendency and entrepreneurship lesson taking.

\section{Conclusion}

The lack of gender influence in terms of the entrepreneurship tendency of the students may have influenced the necessity of the place of the woman in the economic role in society and the idea of providing financial freedom against the male. When we look at the relationship between the schools where pupils are taught and the entrepreneurial tendencies, there is no significant difference between entrepreneurship tendencies and the schools where pupils have studied. ButIt was observed that the average of the entrepreneurial tendency of the "Vocational High School" students was higher than the "Imam Hatip High School" students. Entrepreneurship tendency was found to be higher in the students who took entrepreneurship lessons than those who did not.

In future work; the relationship between entrepreneurship tendencies and cultural phenomena which can give free soul and self-confidence to individuals, and the way of thinking and discussion about entrepreneurship should be analyzed.

\section{Kaynakça}

\section{Kitaplar}

Altunışık, R.,Çoşkun, R., Bayraktaroğlu, S., Yıldırım, E.(2004). Sosyal Bilimlerde Araştırma Yöntemleri. Sakarya: Sakarya Kitabevi,125. 
Arıkan, S.(2004). Girişimcilik Temel Kavramlar ve Bazı Güncel Konular. Ankara: Siyasal Kitabevi.

Bozkurt, Ö.(2011). Dünyada ve Türkiye'de girişimcilik Eğitimi: Başarılı Girişimciler ve Öğretim Üyelerinden Öneriler.Detay Yayıncılık

Durmuş, B., Yurtkoru, S., Çinko, M.(2013). Sosyal Bilimlerde SPSS'le veri analizi. İstanbul: Beta Basım, 118.

Erdoğmuş, N.(2007). Aile İşletmeleri Yönetim Yetki Devri ve İkinci Kuşağın Yetiştirilmesi (2. Baskı). İstanbul: IGİAD Yayınları.

Eyüpoğlu, Dilek (2007), Girişimcilik Eğitimi, Milli Prodüktivite Merkezi Yayınları No:697, Ankara.

Schumpeter, (1973). Competition and Entrepreneurship, The University of Chicago Press, Chicago

\section{Makaleler}

Arslan, M. (2000), A Weberian Approch to Türkish Entreprenuership, Hacettepe Üniversitesi İ.İ.B.F Dergisi, 18 (2), 389.

Balaban, Ö., Özdemir, Y. (2008), Girişimcilik Eğitiminin Girişimcilik Eğilimi Üzerindeki Etkisi: Sakarya Üniversitesi İİBF Örneği. Girişimcilik ve Kalkınma Dergisi, 3(2), 133-147.

Bayrakdar, S.,(2011), Avrupa Birliği Mesleki Eğitim Programlarında Girişimcilik Eğitimlerinin Ekonomik Kalkınmadaki Önemi. C.Ü. Íktisadi ve İdari Bilimler Dergisi, Cilt 12, Sayı 1.

Baysal, H., Özkul, A. S. (2009). Türkiye'de Girişimcilik Eğitiminde İlköğretimin Rolü Ders Kitapları Üzerine Bir İçerik Analizi, I. Uluslararası Davraz Kongresi.

Berk, E.(2009). Girişimcilik dersinin etkililiğginin değerlendirilmesi. Ankara: Milli Ĕgitim Bakanlığ EARGED,

Bozkurt, R.(2000). Girişimci ve Rol Bilinci. Işş Fikirleri Dergisi, 2000 (12), 86-94.

Bozkurt, Ö., Alparslan M.(2013). Girişimcilerde Bulunması Gereken Özellikler İle Girişimcilik Eğitimi: Girişimci ve Öğrenci Görüşleri. Girişimcilik ve Kalkınma Dergisi, 8(1), 10.

Brockhaus, R. H. Horwitz, P. S.(1986). The Psycology of The Entrepreneur, The Art and Science of Entrepreneurship. Massachuset: Bollinger Publishing Company, 25. 
Girişimcilik Eğilimini Etkileyen Faktörlere İlişkin Çok Boyutlu Bir Analiz:

Orta Öğretimde Bir Araştırma

Demircan, N.(2000). Girisimcilik ve Girisimcilerin Kisilik Özellikleri Konusunda Bir Uygulama. Yayınlanmamıs Yüksek Lisans Tezi, Gebze Yüksek Teknoloji Üniversitesi SBE, Kocaeli, 24.

Demirez M., Cebeci, R(2005). Türkiye'de Girişimciliğin Tarihçesi ve Girişimcilerin Sosyolojik Profili. KOSGEB GGM Ulusal Girişimcilik Raporu Bölüm II, 38.

Dollinger, M. J.(1999). Entrepreneurship. Prentice Hall, 4.

Duran, C., Büber, H. ve Gümüştekin, G. (2013), Girişimcilik Hislerine Eğitimin Katkısı: Kütahya Meslek Yüksek Okulu Makine Programı Örneği, Girişimcilik ve Kalkınma Dergisi, 8(2), 33-56.

Gartner, W. B.(1988). Who is an Entrepreneur? Is The Wrong Question. American Journal of Small Business, 12(4), 11.

Girginer, N., Uçkun, Nurullah (2004). İşletmecilik Eğitimi Alan Lisans Öğrencilerinin Girişimciliğe Bakış Açıları: Eskişehir Osmangazi Üniversitesi İ.İ.B.F İşletme Bölümü Öğrencilerine Yönelik Bir Uygulama. 3.Ulusal Bilgi, Ekonomi ve Yönetim Kongresi.

Göksel, A., Aydıntan, B.,(2011). Gender, Business Education, Family Background and Personal Traits; A Multi Dimensional Analysis of Their Effects On Entrepreneurial Propensity: Findings From Turkey", International Journal of Business and Social Science, Vol:2, No:13, July 2011, (35-48)

Hayton, J.C., George, G., ve Zahra, S.A. (2002). National culture and entrepreneurship: A review of behavioral research. Entrepreneurship: Theory \& Practice, 26, 33-52.

Hisrich R., Langan-Fox J. ve Grant S. (2007), Entrepreneurship research and practice: a call to action for psychology. Am Psychol. Sep;62(6):575-89

İbicioğlu, H., Taş, S. ve Özmen, İ. (2010), Üniversite Eğitiminin Girişimcilik Düşüncesinin Değişimine Etkisi: Üniversite Öğrencileri Üzerine Bir Uygulama, Alanya İsletme Fakültesi Dergisi, 2(1), 53-74.

İlhan, S.(2004). Girişimcilik ve Sosyo-Ekonomik Süreçteki Rolü. Doğu Anadolu Bölgesi Araştırmaları, 72.

İpçioğlu, İ., Taşer, A. (2009). İşletme Bölümlerinde Verilen Eğitimin Girişimci Adayı Öğrenciler Üzerindeki Etkileri. Süleyman Demirel Üniversitesi Sosyal Bilimler Enstitüsü Dergisi, 2009/2(10), 
Kalyoncuoğlı S., Aydıntan B., Göksel A.,(2017) The Effect of Entrepreneurship Education on Entrepreneurial Intention: An Experimental Study on Undergraduate Business Students., Journal of Management Research., 9(3), 73-91.

Karadeniz Y., (2010). "Türkiye'de Girişimcilik Eğitimi", http://vizyon21yy.com/documan/Egitim_Ogretim/Onemli_Gunler_Kurulus lar/Girisimcilik_Haftasi/Turkiyede_Girisimcilikv_Egitimi.pdf, (12.01.2013).

Küçüktekin, K.(2006). Girişimcilik Politikası Çerçeversinde Avrupa Birliği’nin KOBİ Politikası ve Avrupa Birliği Müktesebatına Uyum Çerçevesinde Türkiye'nin KOBİ Politikası. Yüksek Lisans Tezi. Atılım Üniversitesi Sosyal Bilimler Enstitüsü Uluslararası Illişkiler Anabilim Dalı. 82.

Lin, B. W., Li, P. C., Chen J. S.(2006). Social Capital, Capabilities, And Entrepreneurial Strategies: A study Of Taiwanese High-Tech New Ventures, Technological Forecasting \& Social Change,73,168-181.

Lundström, A., Stevenson, L.A.(2005). Entrepreneurship Policy Theory and Practice. New York:Springer-Verlag, 41-43.

Meydan C.,Şeşen H.(2011). Yapısal Eşitlik Modellemesi Amos Uygulamaları, Ankara, 21-57.

Mueller, S. T., Anisya S.(2001). Culture and Entrepreneurial Potential: A Nine Country Study of Locus of Control and Innovativeness, Florida International University, Miami, National Academy of Management, Journal of Business Venturing, 16(1), 51-75.

Patır, S., Karahan, M. (2010), Girişimcilik Eğitimi ve Üniversite Öğrencilerinin Girişimcilik Profillerinin Belirlenmesine Yönelik Bir Alan Araştırması, İsletme ve Ekonomik araştırmalar Dergisi, 1(2), 27-44.

Praag, C., Mirjam V.(1999). Some Classic Views on Entrepreneurship, De Economist,147, 322.

Sönmez, A., Toksoy, A.(2014). Türkiye'de Girişimcilik ve Türk Girişimci Profili Üzerine Bir Analiz .Celal Bayar Üniversitesi İ.İ.B.F., Yönetim ve Ekonomi Cilt:21 Sayı:2

Tağraf, H., Halis, M. (2008). Üniversitelerdeki girişimcilik eğitiminin girişimsel öz yetkinlik algısı üzerindeki etkisi: Bir araştırma. Girişimcilik ve Kalkınma Dergisi, 3(2), 91-107. 
Girişimcilik Eğilimini Etkileyen Faktörlere İlişsin Çok Boyutlu Bir Analiz:

Orta Öğretimde Bir Araştırma

TC. Milli Eğitim Bakanlığı Strateji Geliştirme Başkanlığı(2014). Milli Eğitim İstatistikleri Örgün Eğitim 2014-2015. Ankara, 125.

Türkiye Girişimcilik Stratejisi ve Eylem Planı 2014-2016 (2013,Taslak), 83.

Verheul, I.(2003). An Eclectic Theory of Entrepreneurship: Policies, Institutions and Culture. SME's in the Age of Globalization, Ed. David B. Audretsch, Northampton: An Elgar Reference Collection.

Yelkikalan, N.(2010). Dünya ve Türkiye Üniversitelerinde Girişimcilik Eğitimi:

Karşılaştırmalı Bir Analiz. KMÜ Sosyal ve Ekonomik Araştırmalar

Dergisi,12(19), 52-58.

Yılmaz, B. S., Günel, Ö., D. (2011), Üniversite Eğitimi ve Girişimcilik: Bireyleri Girişimciliğe Yönlendiren Etkenler Üzerine Bir Araştırma, Akademik Bakış Dergisi, Sayı (26), 1-20.

Yonca,G.,Atsan,N.(2006). Entrepreneurial Characteristic amongst University Students:Some Insights for Entrepreneurship Education and Training in Turkey

\section{Internet}

Financial Times: Definition of Entrepreneurial Ecosystem. http://lexicon.ft.com/term?term=entrepreneurial-ecosystem adresinden 24.08.2014'da alınmıştır.

Ankara Milli Eğitim Bakanlığı. http://ankara.meb.gov.tr/www/egitimistatistikleri/icerik/24 adresinden 29.04.2015 tarihinde alınmıştır.

KOSGEB Ödülleri.(2013). http://www.turkiyegirisimcileri.org/ sayfalar/sayfa/params/tip-sayfa/id-2/mevzuat.html adresinden 15 Mart 2015 tarihinde alınmıştır. 